\title{
İznik / Nikaia, İstanbul Kapı Kazıları'ndan Pişmiş Toprak Kandiller
}

\author{
Clay Lamps from the Excavation of Istanbul Gate in Iznik / Nicaea
}

\author{
Filiz İnanan* ${ }^{*}$, Mehmet Akçınar** ${ }^{*}$, Tuğba Akçınar ${ }^{* * *} \odot$
}

\section{Öz}

İznik (Nikaia) kentinin dört ana kapısından biri olan İstanbul Kapı ve yakın çevresindeki surların restore edilmesi amacıyla, 2017-2018 yılları arasında İznik Arkeoloji Müzesi başkanlığında, araştırma kazıları gerçekleştirilmiştir. Çalışmamız kapsamında kazı buluntuları içinde yer alan 23 tüm ve tüme yakın pişmiş toprak kandil değerlendirilmiştir. Bu kandillerden biri Pontika üretimi, iki tanesi Kuzey Afrika üretimi, bir tanesi Küçük Asya (Asia Minor) üretimidir. 19 adet kandil ise, İznik kentinde uzun süredir devam eden Antik Roma Tiyatrosu Kazıları'nda rastlanan birebir benzer özellikler taşıyan örnekler doğrultusunda "İznik Yerel Üretim" olarak sınıflandırılmıştır. Bu kandiller, form ve bezeme karakteri itibarıyla Anadolu üretimlerine yakın olmakla birlikte, bilinen Anadolu atölyeleri üretimlerinden bazı farklılıklar da göstermektedir. Bunların dışında iki kandilin dip kısmında saptanan "sarmaşık yaprağı” biçimli kazımanın, atölye işareti (?) olarak kullanılmış olması ihtimali bulunmaktadır. Yüzyıllarca seramik üretimi yapılan Nikaia kentinde 5. ve 7. yüzyıllar arasında kandil üretimi yapıldığı düşünülmektedir. Bu üretimlerin atölye işareti için hem kentin tarihindeki Dionysos kültü hem de İznik kentinin doğa örtüsü ile ilişkili olarak yaprak deseni seçilmiş olması ihtimali göz önünde tutulmalıdır.

Anahtar Kelimeler

Kandil, Bithynia, Yerel üretim, Sarmaşık, Dionysos

\begin{abstract}
Research excavations were carried out between 2017-2018 in order to restore the Istanbul Gate of Iznik (Nicaea) and its surrounding walls. In this study, 23 complete and almost complete clay lamps obtained from the excavations were investigated. One of these 23 clay lamps is a Pontic production, two of them are North African productions and one is an Asia Minor production. Also, the origin of production of 19 clay lamps was identified and classified as "Iznik Local Production". These lamps, probably produced between the $5^{\text {th }}$ and $7^{\text {th }}$ centuries, were compared to the results of the Roman Theatre Excavation and the properties of Anatolian lamp productions such as shape and decoration for identification and classification. Moreover, a "leaf / ivy leaf" motif is identified at the bottom of the two lamps, which was most probably used as a workshop mark in Nicaea. Supportively, the leaf pattern is also associated with both the Dionysus cult and the fertile soil of Nicaea where pottery had been produced for centuries.
\end{abstract}

\section{Keywords}

Lamp, Bithynia, Local production, Ivy, Dionysus

* Sorumlu Yazar: Filiz İnanan (Dr. Öğr. Üyesi), Bursa Uludağ Üniversitesi, Fen-Edebiyat Fakültesi, Sanat Tarihi Bölümü, Bursa, Türkiye. E-posta: inanan@uludag.edu.tr ORCID: 0000-0001-7573-9967

** Mehmet Akçınar, (Uzman Arkeolog), Kültür ve Turizm Bakanlığı, Patara Kazısı, Antalya, Türkiye. E-posta: akcinarmehmet@gmail.com ORCID: 0000-0003-2628-7217

*** Tuğba Akçınar, (Arkeolog), Antalya, Türkiye. E-posta: tugbagokk@gmail.com ORCID: 0000-0002-8642-1965

Atıf: Inanan, Filiz, Akcinar, Mehmet ve Akcinar, Tugba. “iznik / Nikaia, İstanbul Kapı Kazıları’ndan Pişmiş Toprak Kandiller." Art-Sanat, 14(2020): 159-184. https://doi.org/10.26650/artsanat.2020.14.0007 


\section{Extended Summary}

One of the four main gates of Iznik (Nicaea) is the Istanbul Gate and most of it has survived until today. Before the restoration of the gate and the walls, this area was excavated between 2017 and 2018 under the direction of the Iznik Museum, and many findings have been brought to light. Among these findings, a group of clay lamps stands out for their decoration and shape. The aim of this study was to introduce these complete and almost complete clay lamps from the excavation of the İstanbul Gate of Nicaea.

23 clay lamps are catalogued, identified and dated in this study. One of these lamps is of Pontic production since it has common characteristic features of this type of production such as a biconical (with two cones) body, wide, round central part, two opposite-sharp protruding views of the handle and nozzle, a wide filling hole in the circle with a circumscribed circle in the center, vertical-conical knob handle, wideoval wick hole in the nozzle, and slightly raised straight bottom. It is known that this type started to be produced between the end of the $3^{\text {rd }}$ century and the beginning of the $4^{\text {th }}$ century. It is also the most commonly produced type of the $4^{\text {th }}$ century, and its production continued in the second half of the $5^{\text {th }}$ and even in the beginning of the $6^{\text {th }}$ centuries. These types of lamps were unearthed in the ancient settlements of South Russia (Chersonessos, Panticapaion Tyra, Ilurat, Kitey) and Anatolia (Amorium, Nicaea, Isparta/Çünür, Edirne/Hadrianopolis).

Among the clay lamps, there are two lamps, which show characteristic features of North Africa production. The most common features of this type are the knob handle without a groove, a flat edge band with relief, stamped or moulded decorations, a narrow and shallow canal extending from the discus to the nozzle, and a slightly expanding ring base towards the handle. It has been very well established that these lamps were dated to the $5^{\text {th }}$ century, and they were brought from Africa to other settlements between the $4^{\text {th }}$ and $7^{\text {th }}$ centuries. Moreover, it has been determined that one of the clay lamps analysed is an Asia Minor production. It was probably imported into the city of Nicaea between the $4^{\text {th }}$ and $6^{\text {th }}$ centuries.

The other 19 clay lamps and their production center are the main discussion of this study. Even though a workshop or a production center could not be determined precisely for these lamps, they were classified in the same group in terms of their paste (with mica), shape and decoration features. Their shape and decoration motifs are similar to many general features of Anatolian products and this group was most probably produced in Asia Minor. Additionally, very similar lamps to this group have been found in the Roman Theatre of Nicaea, as well. These lamps were classified as Iznik (Nicaea) local production. Due to these reasons, this study suggests that the 19 clay lamps obtained from the Istanbul Gate are linked to these lamps, and could be considered as local productions of Iznik. 
These clay lamps have a rounded body, narrow and long nozzle, hollow discus, one filling hole in the center of discus, and a handle with one or two incised lines. The decoration repertoire generally consists of three or five concentric circles and geometric or floral motifs. In spite of apparent differences in the nozzle parts, they have some similarities with Delos dated to the $5^{\text {th }}$ and $7^{\text {th }}$ centuries. Supportively, the excavation finding in the Roman Theater of Nicaea was dated to the $5^{\text {th }}$ and $7^{\text {th }}$ centuries as well.

Another remarkable point of this group defined by the current study is the "leaf" pattern, which is represented at the bottom of two clay lamps (Cat. No: 5, Cat. No: 21 Kat. No 5). Generally, on the bottom of a lamp is an atelier's mark place. However, the leaf pattern observed in these two clay lamps differs from an atelier's mark. It could be suggested that these lamps are related to the ancient history of Nicaea.

Some significant properties of Nicaea provide a basis for choosing the leaf, which looks like ivy, as a mark of potential local production of clay lamps. As the capital city of Bithynia and the accommodation center for several Roman emperors, Nicaea was an important cult area. Also, it was the sacred city where two ecumenical councils of the Christian world were gathered. These properties created a religiously and politically active history in Nicaea. Moreover, the city has been an important center of pottery production throughout history.

Some stories found in the city are associated with the Pagan god Dionysus (Backhus), as also supported by depictions on ancient coins found in the city. As it is well known, ivy is one of the symbols of Dionysus. "Hederae/ivy" is a motif frequently used in many different works, including architecture, painting and small portable objects in the Roman and Early Christian Worlds. It is also widely used in discus and shoulder decoration of many clay lamps. It is associated with both Dionysus and the fertile soil of Nicaea, where pottery had been produced for centuries.

Although the Istanbul Gate Excavation is finished, some excavations like the Roman Theater Excavation continue in Nicaea. Consequently, while the clay lamp production in the city is being reevaluated with new data, there is no doubt that the variety of lamp forms and decorations will be increased and updated, as well as workshop marks. 


\section{Giriş}

Günümüzde Bursa İli, İznik İlçesi sınırlarında kalan, Nikaia Antik Kenti’nin dört ana kapısından biri olan kuzeydeki İstanbul Kapı ve yakın çevresindeki surların restore edilmesi amacıyla, 06.06.2017-31.10.2018 tarihleri arasında, İznik Müzesi Müdürlüğü başkanlığında, araştırma kazıları gerçekleştirilmiştir ${ }^{1}$. Araştırma kazılarıyla birlikte başlanan sur duvarlarının restorasyon işlemleri hâlen devam etmektedir. Kazı çalışmaları; İç Avlu, İç Avlu Dışı Batı Bölüm, İç Avlu Dışı Doğu Bölüm, İki Sur Arası Batı Bölüm, İki Sur Arası Doğu Bölüm ve İç Sur-Dış Sur Kapıları olmak üzere altı alanda sürdürülmüştür. Çalışmamız kapsamında değerlendirilen pişmiş toprak kandiller İç Avlu, İç Avlu Dışı Batı Bölüm ve İç Avlu Dışı Doğu bölüm alanlarında ele geçmiştir ve kandil buluntularının yerleri İstanbul Kapı planı üzerinde belirtilmiştir (G. 1-G. 2). Kandillerin ele geçtiği İç Avlu'nun doğu bölümünde, kilise/şapel yapısı olduğu düşünülen duvar temelleri ortaya çıkarılmıştır (G. 3). Kilise/şapel yapılarının aydınlatılmasında diğer araçların yanı sıra kandil de kullanıldığı için, bu alanda kandil bulunması şaşırtıcı değildir. Diğer buluntu alanı olan İç Avlu Dışı-Batı Bölüm'de, Roma Dönemi'nde kullanıldığ düşünülen yol, Bizans Dönemi kanalizasyon sistemi ile yer yer korunmuş olan Geç Roma Dönemi mozaik döşeme tespit edilmiştir (G. 4). Bu alanda, işlev açısından kandillerle doğrudan bağlantı kurulamaz fakat Geç Roma-Erken Bizans Döneminde kullanımda olduğu düşünülen mozaikli zemin ve kanalizasyon çevresinde bulunan kandiller, buluntu alanına tarihsel açıdan uygunluk taşımaktadır. Kandil ele geçen üçüncü alan ise İç Avlu Dış1-Doğu Bölüm'dür. Bu alanda tanımlanamayan birçok yapıya ait duvarlar ile sıvalı havuzlardan oluşan 3 farklı evre tespit edilmiştir ancak saptanan mekân ve kullanım evreleri ile kandiller arasında bağlantı kurulamamıştır (G. 5).

1 Araştırma kazıları, Turizm ve Kültür Bakanlığı'nın 51337267-160.02.02-E40377 Sayılı izni ile İznik Müzesi Müdürü Haydar Kalsen başkanlığında, Prof. Dr. Sait Başaran'ın bilimsel danışmanlığında yürütülmüştür. Uzman Arkeolog Mehmet Akçınar, Arkeolog Tuğba Akçınar ve Restoratör Murat Olçay kazı ekibinin alan sorumluları olarak görev almıştır. Seramikler, Dr. Öğr. Üyesi Filiz İnanan tarafından ekip üyelerinin katkılarıyla belgelenmiştir. Restorasyon çalışmaları Sama İnşaat tarafından gerçekleştirilmiştir. 


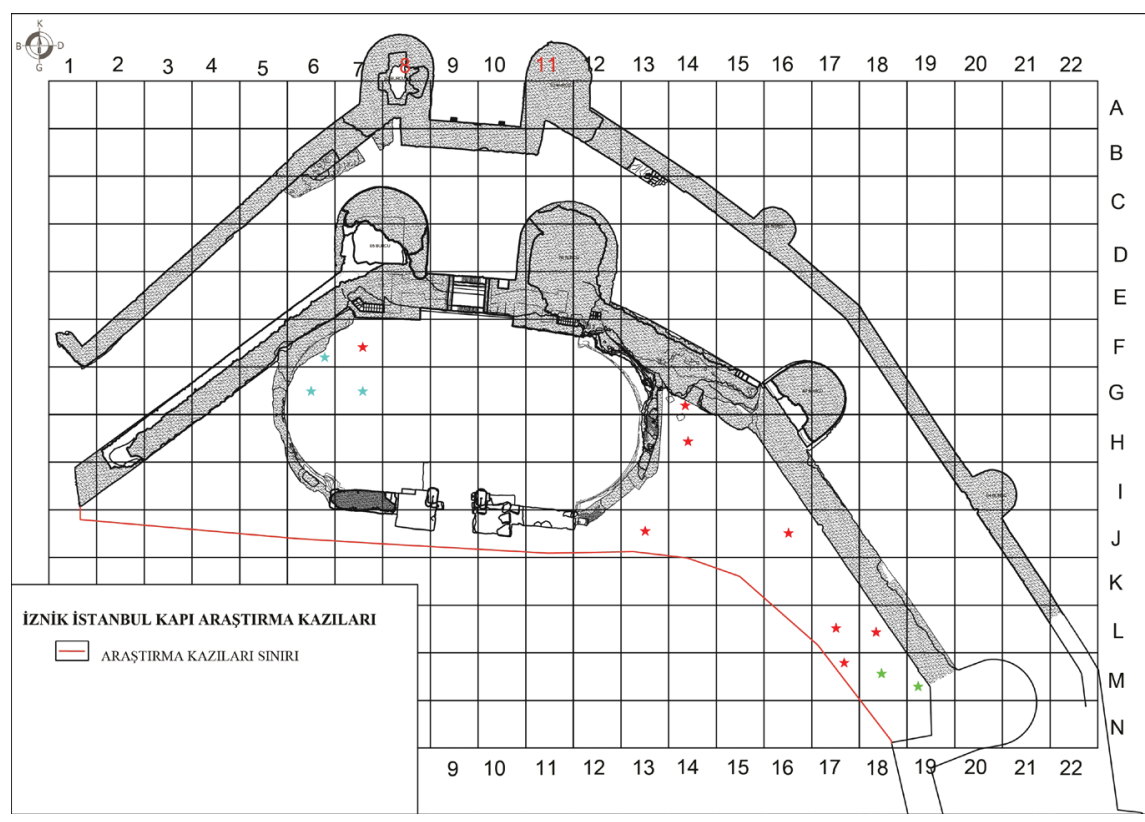

G. 1. İstanbul Kapı Kazıları Planı (Kuleli Mimarlık - Sama İnşaat, 2017)

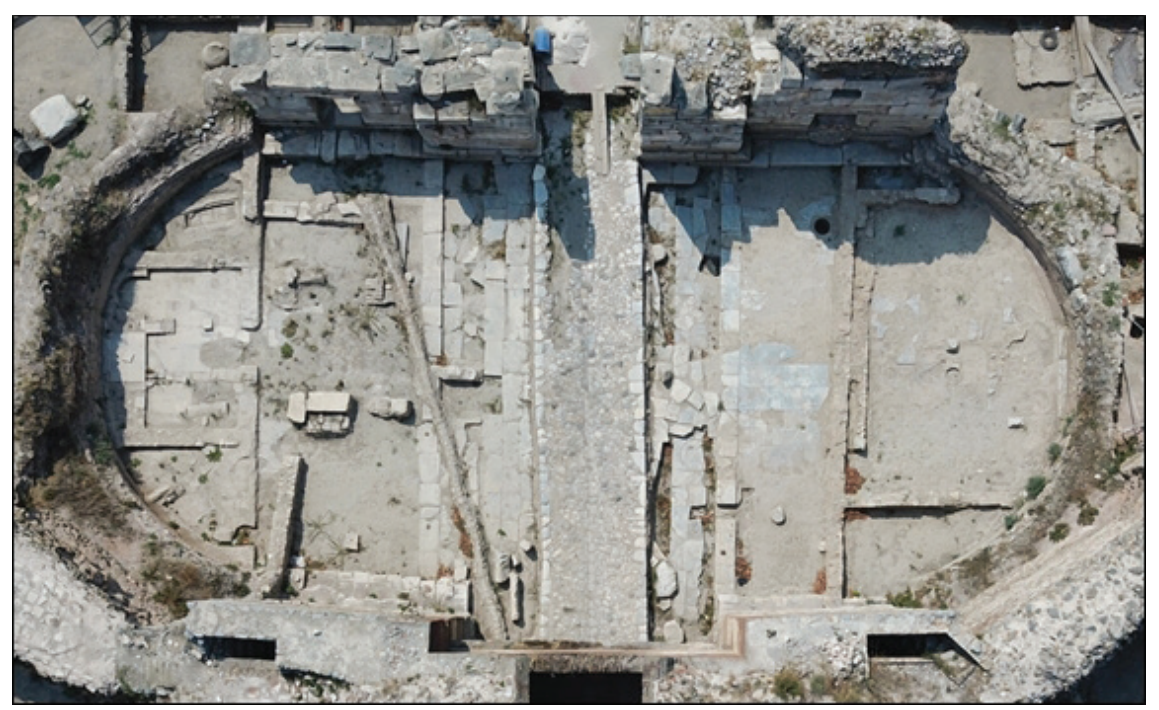

G. 2. İstanbul Kapı Kazıları - İç Avlu Doğu ve Batı Bölüm - Genel Görünüm (Sama İnşaat-Bursa Büyükşehir Belediyesi, Harita Birimi, 2018) 


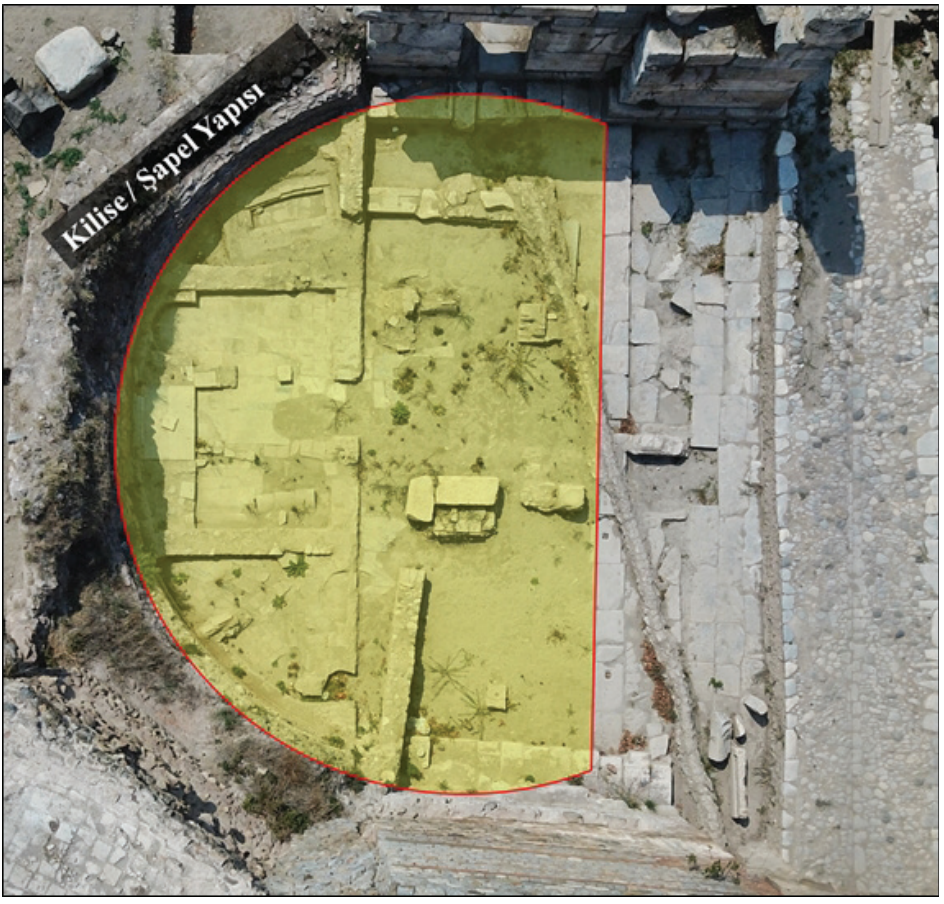

G. 3. İç Avlu Doğu Bölüm - Kilise Şapel Yapısı (Sama İnşaat-Bursa Büyükşehir Belediyesi, Harita Birimi, 2018)

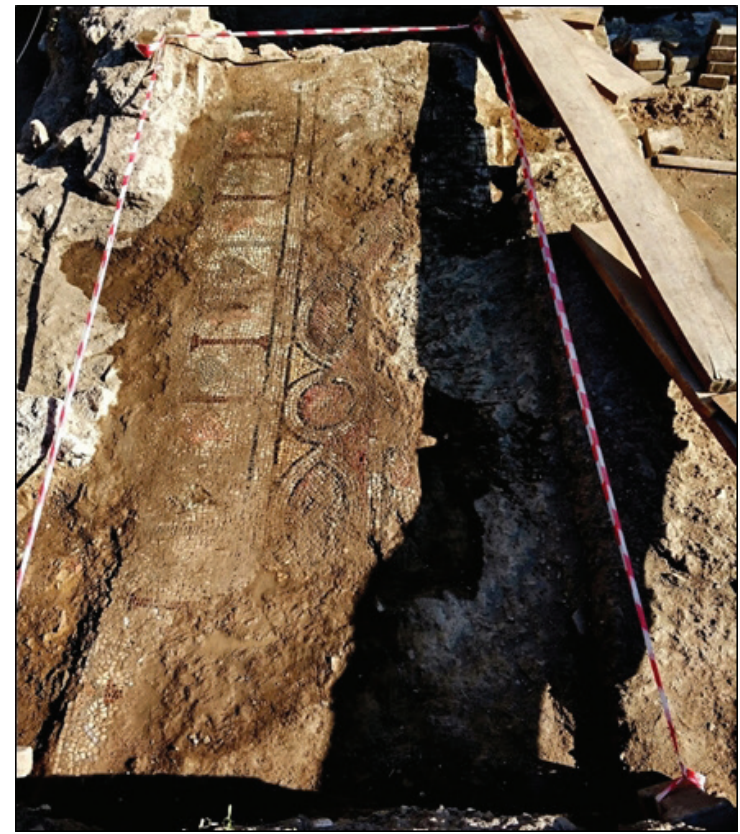

G. 4. İç Avlu Batı Bölüm - Mozaik Taban Döşemesi (M. Akçınar, 2018) 


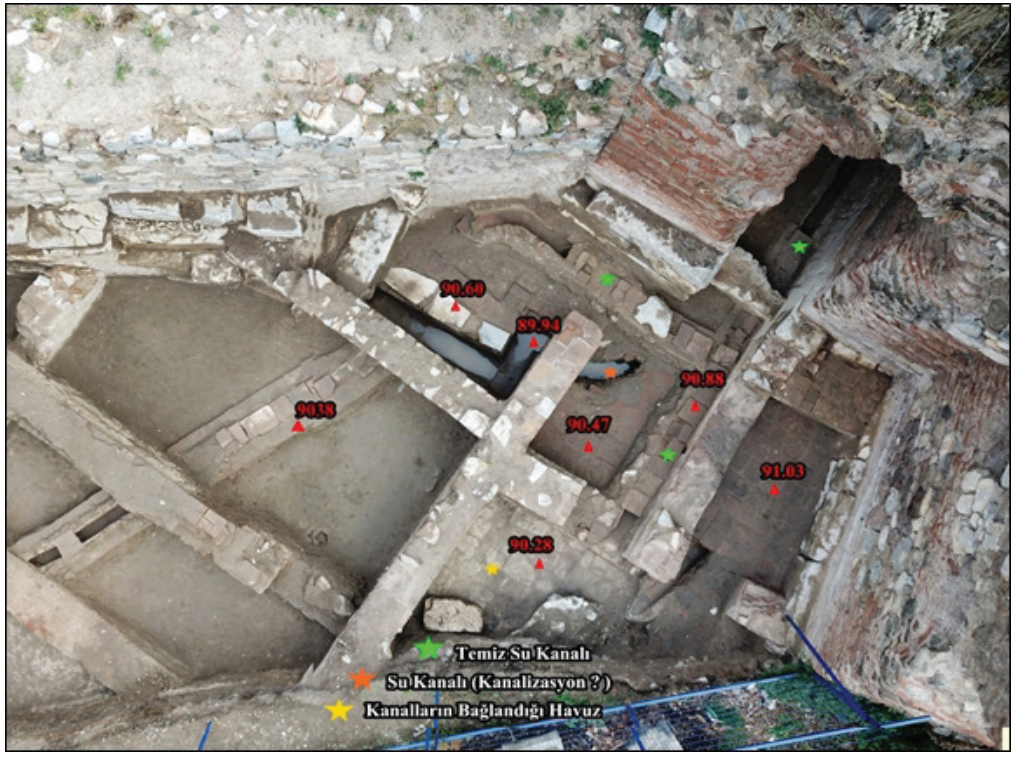

G. 5. İç Avlu Dış1 Doğu Bölüm (Sama İnşaat-Bursa Büyükşehir Belediyesi, Harita Birimi 2018)

\section{İstanbul Kapı Kazılarında Ele Geçen Kandil Grupları}

İznik (Nikaia) İstanbul Kapı ve yakın çevresinde gerçekleştirilen araştırma kazılarında, 23 adet tüm ve tüme yakın pişmiş toprak kandil ele geçmiştir. Bu kandiller Pontika, Kuzey Afrika ve Küçük Asya üretimleri ana bölümleri altında gruplandırılmıştır. Kronolojik açıdan kandiller içindeki en erken tarihli örnek Pontika üretimi kandildir. Bir adet tüm örnekle temsil edilen bu grup, kataloğumuzda ilk sıraya yerleştirilmiştir. Kuzey Afrika üretimi kandillerden tüm ve tüme yakın iki kandil bulunmaktadır. Küçük Asya Üretimleri ise iki ana gruba ayrılmıştır. Bir kandil, üretim yeri tespit edilmemiş olan Küçük Asya (Asia Minor?) üretimi adıyla tasniflenmiştir. Çalışmamızın önemli kısmını oluşturan tümü kalıp yapımı 19 adet kandil, yine Küçük Asya üretimleri içinde değerlendirilmiştir ancak bu kandiller az mika, az taşçı ve az kalsit katkılı, orta sert hamur yapısı, form ve bezeme özellikleri açısından homojen bir grup oluşturarak diğer örnekten aynı zamanda daha gözenekli hamur yapısıyla da ayrılmaktadır. İznik'te uzun yıllardır sistematik olarak sürdürülen ${ }^{2}$ ve çok fazla sayıda ve çeşitlilikte buluntu veren İznik Roma Tiyatrosu Kazıları buluntuları arasında yivli ve delikli kulplu ve geniş gövdeli formdaki kandiller göz önüne alınarak "İznik Yerel Üretim” adıyla sınıflandırılmıştır. Konteksiz ele geçen İstanbul Kapı buluntuları, stratigrafik açından güçlü veriler sunan Roma Tiyatrosu Kazıları kandil buluntuları referans alınarak yapılmıştır³.

2 İznik Roma Tiyatrosu Kazıları ilk olarak 1980 yılında Bedri Yalman tarafından başlatılmıştır. 2016 yılından itibaren Doç. Dr. Aygün Ekin Meriç danışmanlığında yürütülen kazılarda İznik'in yüzlerce yıllık tarihini belgeleyen çok sayıda ve çok çeşitlikte buluntu ele geçmektedir. Aygün Ekin Meriç, "İznik Tarihini Simgeleyen Bir Anıt: Antik Roma Tiyatrosu”, Dokuz Eylül Üniversitesi Sosyal Bilimler Enstitüsü Dergisi 21/2 (2019), 341.

3 Aygün Ekin Meriç, "Late Roman Pottery From the Theatre of Nicaea in Bithynia", Anatolia Antiqua XXVI (2018), 76. 


\section{Pontika Üretimi Kandil (Kat. No:1)}

İstanbul Kapı kandilleri arasında 1 adet tüm Pontika üretimi kandil bulunmaktadır (Kat. No:1). Kuzey Pontika'da popüler olan bu tipin kesin üretim yeri henüz saptanmamıştır. Ancak kil ve form özellikleri açısından Küçük Asya üretimi kandiller içinde değerlendirilmektedirler. Türkiye, Güney Rusya ve Bulgaristan gibi birçok bölgeye yayılan bu kandillerde, bikonik (iki konili) gövdeli, geniş yuvarlak merkezi kısım, kulp ve burunun iki karşıt-keskin çıkıntılı görünüm, merkezde çevresi yükseltilmiş daire içinde geniş bir doldurma deliği, dikey-konik topuz kulp, burunda geniş-oval fitil deliği, hafif yükseltilmiş düz dip karakteristik özelliklerdir. Bu tipin 3. yüzyıl sonu ile 4. yüzyıl başı arasında üretilmeye başlandığı, 4. yüzyılın en çok üretilen tiplerinden biri olduğu, 5. yüzyılın ikinci yarısında hatta 6 . yüzyıl başlarında üretiminin devam ettiği belirtilmektedir ${ }^{4}$. Bu tip kandiller; Anadolu dışında Güney Rusya Antik kentlerinde (Khersonessos, Pantikapeon Tyra, Ilurat, Kitey) bulunmuştur. Antik kentler dışında Bulgaristan Müzeleri ${ }^{5}$ ve Paul Getty Müzesi' ${ }^{6}$ koleksiyonlarında da benzer örnekler mevcuttur. Anadolu'da ise Amorium ${ }^{7}$ ve İznik (Roma Tiyatrosu kazıları) ${ }^{8}$ kazılarında bu tip kandiller ele geçmiştir. Isparta/Çünür' $\mathrm{de}^{9}$ bir mezar yapısında yarım ay formlu olarak tanımlanmış benzer bir kandil yer almaktadır. Edirne (Hadrianopolis) Kalesi $i^{10}$ ve surlarının kurtarma kazılarında benzer kandiller bulunmuş, "kayık tipi" adıyla sınıflandırılmış ve 4 . yüzyıla tarihlendirilmiştir ${ }^{11}$. Bikonik formları açısından İstanbul Kapı kandiline benzeyen bu kandiller, omuz çevrelerindeki kabartma bezemeler açısından farklı özelliklere sahiptir.

Kat. No: 1 (G. 6-a). Kazı Envanter No: 167. Buluntu Yeri: G 14 Plankaresi. Buluntu Seviyesi: +90.73 -90.30 Hamur Rengi: 10 R 4/6. Astar Rengi: 7. 5 YR 8/3. Az taşçık, az mika katkılı hamur serttir. Uzunluk: $8.1 \mathrm{~cm}$. Genişlik: $5.5 \mathrm{~cm}$. Yükseklik: $4.5 \mathrm{~cm}$. Kaide Çapi: $2.4 \mathrm{~cm}$. Bezemeler: Diskus: Bezemesiz, merkezde çevresi yükseltilmiş daire içine geniş bir doldurma deliği bulunur. Omuz: Bezemesizdir. Burun: Yanma izleri belirgindir. Kulp: Konik-topuz kulpludur. Üretim Yeri: Kuzey Pontika

4 Laurent Chrzanovski ve Denis Zhuravlev, Lamps From Chersonesos in the State Historical Museum Moscow (Rome: L'ERMA di Bretschneider,1998), 141.

5 Chrzanovski ve Zhuravlev, Lamps From Chersonesos in the State Historical Museum Moscow, 141.

6 Jean Bussière ve Birgitta Lindros Wohl, Ancient Lamps in the J. Paul Getty Museum (Los Angeles: J. Paul Getty Museum, 2017), 395, 542.

7 Chistopher S. Lightfoot, Amorium Report 2. Research Papers and Technical Reports (Oxford: Bar international series 1170, 2003), 102-105.

8 Ekin Meriç, "Late Roman Pottery From the Theatre of Nicaea in Bithynia," 87, Pl. 9.

9 Murat Fırat tarafından bu formdaki kandillerin hamur ve profil özellikleri açısından Anadolu'daki kurtarma kazılarında ele geçen benzer kandiller ayrıntıyla değerlendirilmiştir. Murat Fırat, "A Vaulted Tomb in Isparta/ Çünür and Its Finds". Arkeoloji Dergisi XXI, (2016), 129.

10 Hasan Karakaya, "Edirne (Hadrianopolis) Kalesi 2008 Y1lı Kurtarma Kazıları”, Müze Kurtarma Kazıları Semineri 18 (2010), 132, Resim 13-b.

11 Günsel Dağl1, "Hadrianoupolis Surları Kurtarma Kazısında Bulunan Roma ve Bizans Dönemi Kandilleri" (Yüksek Lisans Tezi, Dokuz Eylül Üniversitesi 2008), 32. 
(?) Benzer Örnekleri: Ekin-Meriç 2018: Plate 8-47; Fırat 2016: 138-Fig.6; Karakaya 2010: 132-Resim 13-b; Dağlı 2008: Kat. No: Şekil 458/Levha LI, Şekil 469/Levha LV; Chrazanovski-Zhuravlev 1998: No:82, No:83; Bussière-Wohl 2017: 395-Cat. no: 542. Tarihlendirme: 4.yüzyıl-5.yüzyıl.

\section{Kuzey Afrika Üretimi Kandiller (Kat. No: 2-3)}

O. Broneer, Korinth kandil kataloğunda bu tip kandilleri Tip XXXI olarak sinıflandırılmıştır. O. Broneer, Geç Roma ve Erken Hristiyanlık arasında tarihsel bir kesinti olmadığını hatırlatırken, Hristiyan sembolleri taşıyan ve Tip XXVIII olarak gruplandırılan bir kandil ile pagan motifleri taşıyan aynı tipte başka bir kandilin birbirinden farklı değerlendirilmemesi gerektiğini belirtir. Ancak Geç Roma kandillerinde bazı Hristiyan unsurlara rastlanmasına karşın, Tip XXXI kandillerinin hiçbirinde pagan motif tespit edilmediğini, dolayısıyla tamamen Hristiyan karakterli oldukları ayrıntısinı önemle vurgular ${ }^{12}$.

Bilinen tüm örnekleri kalıpla üretilmiş olan bu kandil tipinin en yaygın özellikleri; topuz-tutamak biçimli ve yivsiz, oluksuz kulp, dekorasyonlu düz bir kenar bandı, diskustan burun deliğine uzanan dar ve yüzeysel kanal ile kulpa doğru hafifçe genişleyen halka kaidedir ${ }^{13}$. Ancak İstanbul Kapı kandil buluntusu, bu tipin karakteristik tutamak veya topuz kulpundan farklı olarak yuvarlak kulpa sahiptir. Bu grup kandillerde süslemeler genellikle diskusu çevreleyen bant üzerinde ve diskusta yer almaktadır. Hurma dalını anımsatan ringa balığı kemiği gibi Geç Roma ve Hristiyan kandillerinde görülen ortak motiflerin dişında, çoğunlukla bu tipe özgü, başka bir deyişle önceki kandillerden farklı özelliklere sahip Hristiyan sembolleriyle bağlantılı motifler kullanılmıştır. Hristiyan kilisesi motiflerinde görülen küçük palmiye/hurma ağacı, kuşlar, üçgenler, çarklar, kalpler bu kandillerde sıklıkla karşımıza çıkar. Diskus bezemelerinde, motif yine Hristiyan temaları içermektedir ${ }^{14}$.

D. M. Bailey, bu kandil tipinin başlıca üretim yerinin Tunus olduğunu belirterek "Afrika-Bizans" kandilleri adı altında kataloglamış ve 400-500 yılları arasına tarihlendirmiştir ${ }^{15}$. A. Karivieri bu grubun 5. yüzyıl sonu-6. yüzyıl başı arasında Atina’ya

12 Oscar Broneer, Corinth: Terracotta Lamps, vol. IV, part II (Massachusetts: American School of Classical Studies at Athens, 1930), 118.

13 Oscar Broneer, Isthmia: Terracotta Lamps, vol. III (Princeton: American School of Classical Studies at Athens, 1977), 81.

14 Bu ortaklığın sebebinin ringa kemiğinin kabartmalardaki görüntüsünün hurma dalıyla olan benzerliği olabileceği düşünülmektedir. Hurma dalının sembolik anlamı, tek tanrılı dinlerde oldukça güçlüdür. Broneer, Corinth: Terracotta Lamps, 118.

15 Donald Michael Bailey, A Catalogue of the Lamps in the British Museum, III. Roman Provincial Lamps, (London: British Museum Publications, 1988), 190-210. 
ithal edildiklerini ${ }^{16}$; J. Perlzweig, Attika'ya 4. ve 7. yüzyıllar arasında getirildiklerini ${ }^{17}$; L. Chrzanovski ve D. Zhuravlev ise Khersonessos buluntuları arasındaki benzer örneğin Kuzey Afrika'dan ithal edildiğini ve 5. yüzyılın ikinci yarısına tarihlendirildiğini belirtmiştir ${ }^{18}$. Argos buluntuları içindeki benzer kandiller 5. ve 7. yüzyıllar arasına tarihlendirilirken ${ }^{19}$, Sakız (Chios) Adası'ndaki Kuzey Afrika kandillerinin 7. yüzyıl ortalarına kadar kullanıldıkları ileri sürülmüştür ${ }^{20}$.

Kat. No: 2 (G. 6-b). Kazı Envanter No: 212. Buluntu Yeri: J 16 Plankaresi. Buluntu Seviyesi: +90.96-90.54 Hamur Rengi: 7.5 YR 4/8. Astar Rengi: 7. 5 R 4/8. Az mika katk1lı hamur serttir. Uzunluk: $10.2 \mathrm{~cm}$. Genişlik: $5.9 \mathrm{~cm}$. Yükseklik: $4.1 \mathrm{~cm}$. Kaide Çapı: $3.3 \mathrm{~cm}$. Bezemeler: Diskus: Dört yapraklı yonca motifi, her yaprak arasina birer palmet motifi yerleştirilmiş. Omuz: Tüm omuzda kesintisiz devam eden ikişerli, uçları spiralle sonlanan "S" biçimli geometrik desenler, her iki desen birer şevron ile ayrılmış. Kaide altında iki eşmerkezli daire kazıma bulunmaktadır. Burun: Kırık ve noksan, yanma izleri belirgindir. Kulp: Delikli, iki yivli kulpludur. Üretim Yeri: Kuzey Afrika-Tunus. Benzer Örnekleri: Broneer 1930: Plate XXII-1454; Bailey 1988: Cilt III- Pl.22-Q1779-1792, Pl.23-Q1793-1800, Pl.24-Q1801-1809, Pl.25-Q1810-1822, P1.27-Q1832-1834, P1.28-Q1837-1841; Bruneau 1965: Plate 33-4691; İnanan 2007: 63-9/64-1; Topoleanu 2012: Planşa XIV-112-113. Tarihlendirme: 5.yüzyıl baş1-6.yüzy1l başı.

Bu kandil (Kat. No: 2), Roma dönemi Afrika eyaletlerinde üretilen Broneer Tip XXXI varyasyonlarından biridir. Tek parçalı topuz kulplu, oval gövdeli kandilde hiçbir bezeme bulunmamaktadır. British Museum kataloğunda bulunan bir benzeri Bailey tarafından 4. yüzyıl sonu ile 5. yüzyıla tarihlendirilmiştir ${ }^{21}$. Broneer'in Tip XXXI kandilleri, Kat. No. 3 kandil buluntusuyla, oval gövde ve tutamamak kulp olmak üzere iki ana özelliği paylaşmaktadır. Ancak Broneer'in sınıflandırdığı kandillerin çoğunda omuz bezemesi, Kırmızı Astarlı Kuzey Afrika kandillerinde olduğu gibi düz zeminde bask1 veya kabartma teknikleriyle uygulanmıştır ${ }^{22}$. Broneer, Isthmia kenti buluntuları içindeki bu Hristiyan kandillerinin prototipinin bezemelerinde Eski ve Yeni Ahit'ten esinlenilen motifler bulunduğunu, Yunanistan ve Kuzey Afrika üretimi ve genellikle iki veya üç doldurma delikli olduklarını belirtmiştir ${ }^{23}$. Bu sebeple Bailey'in kullandığ1

16 Arja Karivieri, The Athenian Lamp Industry in the Late Antiquity (Helsinki: Foundation of the Finnish Institute at Athens, 1996), 253.

17 Judith Perlzweig, Lamps of the Roman Period, First to Seventh Century after Christ Agora VII (New Jersey: American School of Classical Studies at Athens, 1961), 18.

18 Chrzanovski ve Zhuravlev, Lamps From Chersonesos in the State Historical Museum Moscow, 159.

19 Anne Bovon, Lampes d'Argos (Études péloponnésiennes V) (Paris: Librairie Philosophique J. Vrin, 1966$), 85$.

20 John Boardman vd., Excavations In Chios 1952-1955, Byzantine Emporio (Athens: British School at Athens, 1989), 118.

21 Bailey, A Catalogue of the Lamps in the British Museum, III. Roman Provincial Lamps, 202.

22 Broneer, Isthmia: Terracotta Lamps, vol. III, Plate 36 / 3150.

23 Broneer, Isthmia: Terracotta Lamps, vol. III, 81. 
varyasyon kelimesi önemlidir. Kat. No: 3 kandilinin Broneer Tip XXXI'den türemiş, onlarla yakın zamanlı veya ihtimalle biraz daha geç tarihli kandiller olabileceği ihtimali göz ardı edilmemelidir.

Kat. No: 3 (G. 7- a) Kazı Envanter No: 202. Buluntu Yeri: M 18+M 19 Plankareleri. Buluntu Seviyesi: +90.96 -90.80 Hamur Rengi: 7.5 R 5/12. Astar Rengi: 7. 5 R 5/12. Az mika, az kalsit katkılı hamur orta serttir. Uzunluk: $9.1 \mathrm{~cm}$. Genişlik: 5.7 cm. Yükseklik: $4.2 \mathrm{~cm}$. Kaide Çapı: $3.2 \mathrm{~cm}$. Bezemeler: Diskus: Bezemesiz, bir doldurma deliklidir. Omuz: Bezemesizdir. Burun: Yanma izleri belirgindir. Kulp: Topuz kulpludur. Üretim Yeri: Kuzey Afrika-Tunus (?). Benzer Örnekleri: Bailey 1988: Plate 28-Q1843; Broneer 1977: Plate 36-3150. Tarihlendirme: 4. yüzyıl sonu-5. yüzyıl.

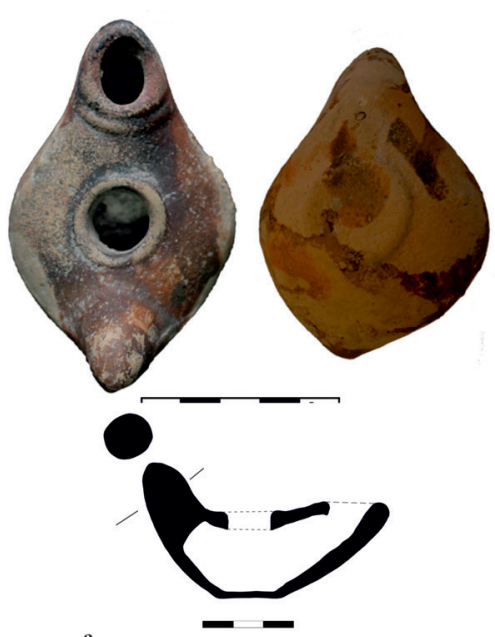

a.

G. 6. Kat. No: 1 - Kat. No: 2 (F. İnanan, M. Akçınar, T. Akçınar, 2018)
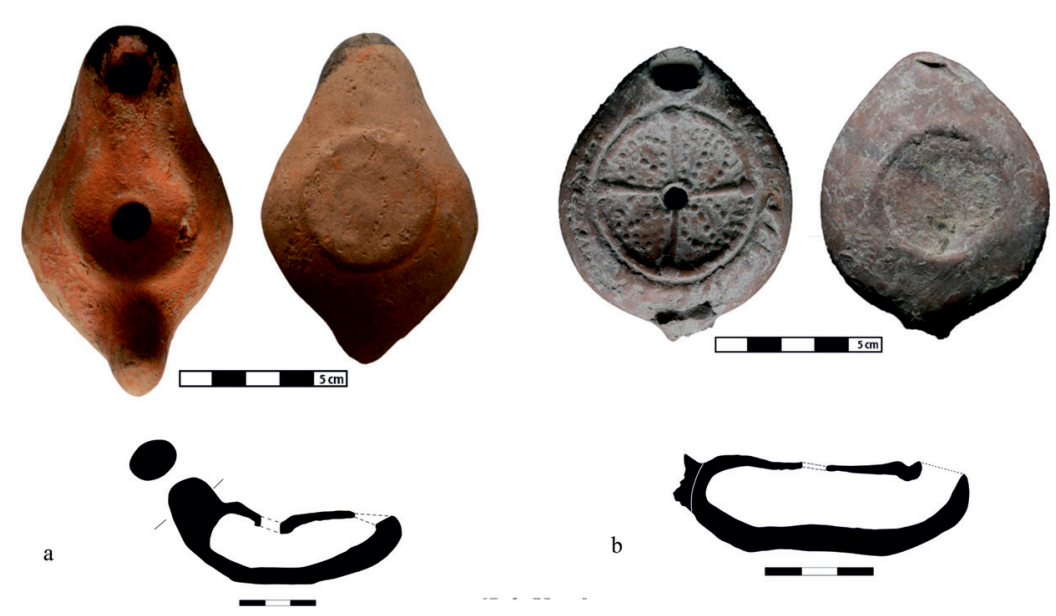

G. 7. Kat. No:3 - Kat. No:4 (F. İnanan, M. Akçınar, T. Akçınar, 2018)

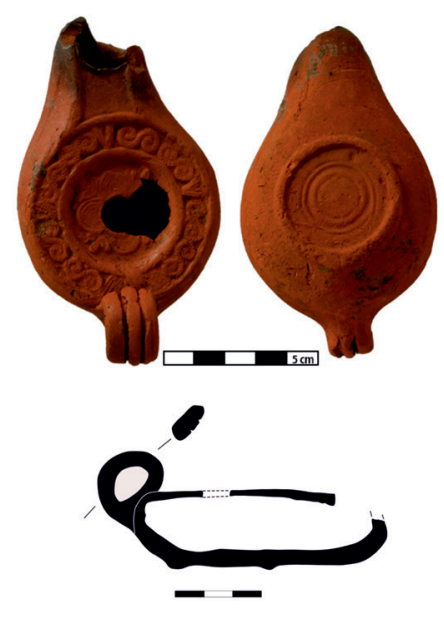

b. 


\section{Küçük Asya/Anadolu Üretimleri ve Yerel Üretim Kandiller}

İznik, İstanbul Kapı buluntuları içindeki kandillerin birçoğu form ve bezeme stili açısından Anadolu'daki kandil üretim merkezlerinin mallarına yakınlık taşımaktadır. Ancak bu kandillerin atölyesi kesin olarak tespit edilememiştir. Bunun yanında içlerinde, kendilerine özgü bazı farklı özellikler taşıyan örnekler mevcuttur. Bu kandiller, çalışmamızda Küçük Asya/Anadolu üretimi (üretim merkezi bilinmeyen) kandiller ve yerel (İznik ?) üretim kandiller olarak iki ana gruba ayrılarak incelenmişlerdir. İznik yerel üretim olarak sınıflandırılan kandiller, bezeme özellikleri göz önüne alınarak iki alt gruba ayrılmıştır.

\section{Küçük Asya / Anadolu Üretimleri (?) (Kat. No:4)}

Diğer gruplardaki örneklerden ayrılan, kalıp üretimi bu kandil (Kat. No: 4), O. Broneer'in Isthmia Geç Roma ve Erken Hristiyanlık Dönemi kandilleri kataloğundaki Tip XXVII kandilleriyle benzerlik taşımaktadır. Broneer bu tipi, kırmızı veya koyu kahverengi hamurlu bir alt grup olarak tanımlamıştır. Genellikle yivli ve yekpare kulplu olan kandillerin bir kısmının bezemesinde Hristiyan monogramlarının kullanıldığını, bazılarında birden fazla doldurma deliği bulunduğunu belirtmiştir. Hristiyan motifi içeren bu tip kandilleri 4. yüzyıl başı ile 5. yüzyıl başı aralığına tarihlendirmiştir ${ }^{24}$. Bruneau ise Delos buluntuları arasındaki benzer bir kandilin Küçük Asya üretimi olduğunu ve 7. yüzyıla kadar tarihlendirilebileceğini ifade etmiştir ${ }^{25}$. Anadolu yerleşimlerinden ve önemli üretim merkezlerinden biri olan Knidos kandillerinin 5. yüzyıl üretimleri arasında, bu kandile benzeyen formda örnekler mevcuttur ancak dekorasyon stili ve motifler farkl1dir ${ }^{26}$.

Kat. No: 4 (G. 7-b) Kazı Envanter No: 111. Buluntu Yeri: F 7 Plankaresi (Sondaj). Buluntu Seviyesi: +89.92-89.61 Hamur Rengi: 7. 5 R 5/6. Astar Rengi: 7. 5 R 5/6. Az kalsit katkılı hamur serttir. Uzunluk: $8.2 \mathrm{~cm}$. Genişlik: $6.7 \mathrm{~cm}$. Yükseklik: $2.6 \mathrm{~cm}$. Kaide Çapı: 3.6 cm. Bezemeler: Diskus: Uçları kabartma noktalarla sonlandırılmış dört haç kolu, haç kolları arasında çevre çizgileri küçük kabartma noktalarla oluşturulmuş birer daire bulunur. Ayrıca bu dairelerin hepsinin ortasında düz çizgi oluşturacak şekilde dizilmiş dörder kabartma nokta mevcut. Omuz: Kesintisiz bir bant hâlinde devam eden, birbirine eşit olmayan, düzensiz, kısa, dar kazıma çizgiler. Burun: Yanma izi yok. Kulp: Kırık ve noksandır. Üretim Yeri: Küçük Asya (Asia Minor?) Benzer Örnekleri: Bruneau 1965: Plate 34-4720; Broneer 1977: Plate 10-3037 (Type XXVIII); Bailey 1988, Plate 97-Q2995, Q2996, Q2997. Tarihlendirme: 4.yüzyıl sonu-5.yüzyıl.

24 Broneer, Isthmia: Terracotta Lamps, vol. III, 78.

25 Philippe Bruneau, Les Lampes, Exploration Archéologique de Délos, XXVI (Paris, Éditions de Boccard, 1965), 142.

26 Bailey, A Catalogue of the Lamps in the British Museum, III. Roman Provincial Lamps, Plate 97- Q 2995, Q 2996, Q2997. 


\section{Küçük Asya / Yerel (İznik ?) Üretim Kandiller}

\section{Grup: Eşmerkezli Daire Bezemeli Kandiller (Kat. No: 5-12)}

İznik, İstanbul Kapı kandillerinin 19 tanesi diğer kandillerden hamur, form ve dekorasyon açısından ayrılarak homojen bir grup oluşturmaktadır. Bu kandillerin form ve dekorasyonlarının genel özellikleriyle Anadolu üretimleri içinde değerlendirilmesi uygundur. Tümü kalıp üretimi olan kandiller, bezeme özelliklerine göre iki alt grup altında incelenmiştir. İlk grupta az mika, az taşçık ve az kalsit katkılı ve orta sert hamurlu, yuvarlak gövdeli, dar ve uzun burunlu, derin diskuslu, diskus merkezi tek doldurma delikli, bir veya iki yivli, delikli kulpa sahip kandiller bulunmaktadır. Formları birbirine benzeyen bu kandillerin bezeme özellikleri de ortaktır. Bu gruba alınan 8 kandilin (Kat. no: 5, 6, 7, 8, 9, 10, 11, 12) diskusunda üç veya beş eşmerkezli daire kabartma mevcuttur. Hiçbirinin omuz ve burun kanalı üzerinde bezeme bulunmamaktadır. $\mathrm{Bu}$ gruptaki tek bir kandilin (Kat. No: 5) dip kısmında atölye işareti olarak hazırlanmış olabilecek "yaprak" kazıma bulunmaktadır. Çalışmamız kapsamındaki bu kandillerin, İznik kentinde başka alanlarda bulundukları görülmüştür. Ancak Anadolu içinde ve dışında dağılım gösterdikleri başka bir yerleşim tespit edilememiştir. A. Ekin Meriç tarafından yayınlanan İznik, Roma Tiyatrosu kazı buluntuları arasında bu tipe benzeyen kandiller, araştırmacı tarafından "Yerel üretimler" adıyla sınıflandırılarak 5. ve 7. yüzyıllar arasına tarihlendirilmiştir. Söz konusu yayındaki kandillerde atölye işaretinin varlığına ilişkin bilgi verilmemiştir ${ }^{27}$. İznik dışında sadece Delos’ta nispeten benzer bir form saptanmıştır. Delos'ta bulunan kandil, İstanbul Kapı kandillerine göre daha kısa burunludur ve 5 . ve 7 . yüzyıllara tarihlendirilmiş ${ }^{28}$. Küçük Asya bölgesinin önemli kandil üretim merkezi olan Ephesos (Efes) kandillerinde tutamak kulplu ve benzer bezemeye sahip, 6. ve 7. yüzy1llara tarihlenen örnekler mevcuttur ancak İstanbul Kap1 kandilleri form özellikleri açısından Ephesos üretimi kandillerden ayrılmaktadırlar. ${ }^{29}$.

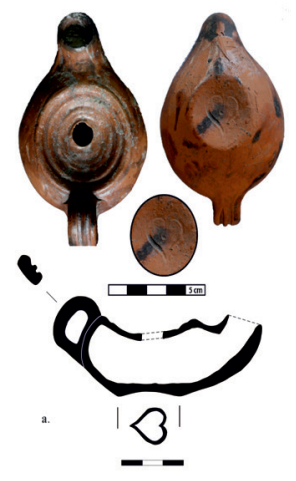

G. 8. Kat. No: 5
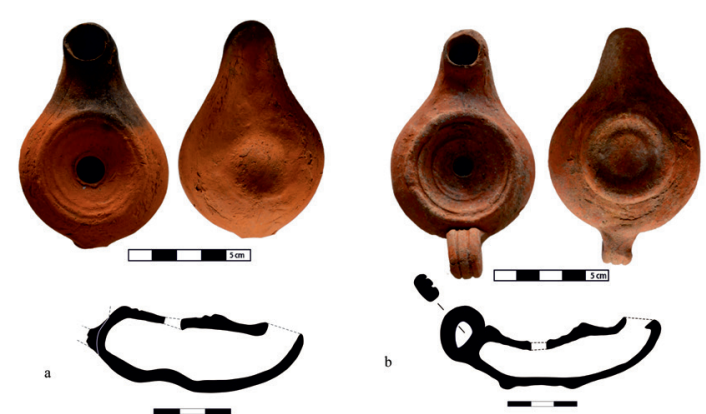

G. 9. Kat. No: 6 ve 7 (F. İnanan, M. Akçınar, T. Akçınar, 2018)

27 Ekin Meriç, "Late Roman Pottery From the Theatre of Nicaea in Bithynia", 75.

28 Bruneau, Les Lampes, Exploration Archéologique de Délos, XXVI, 142.

29 Ephesos kandillerinin bu tipe yakın örnekleri için bkz. Franz Miltner, Das Cömeterium der Sieben Schlöfer, Forschungen in Ephesos IV/2 (Wien, 1937), Pl. VI-No. 1131; Bailey, A Catalogue of the Lamps in the British Museum, III. Roman Provincial Lamps, Vol. III, P1. 105; Angeliki Katsioti, The Lamps of Late Antiquity From Rhodes, 3rd-7th centuries AD (Oxford: Archaeopress Archaeology, 2017), 302-AM 227. 
Kat. No: 5 (G. 8) Kazı Envanter No: 203. Buluntu Yeri: M 18+M 19 Plankareleri. Buluntu Seviyesi: +90.80-90.38 Hamur Rengi: 2.5 YR 4/6. Astar Rengi: 2.5 YR 5/6. Az mika, az kalsit katkılı hamur orta serttir. Uzunluk: $10 \mathrm{~cm}$. Genişlik: $6.5 \mathrm{~cm}$. Yükseklik: 4.2 cm. Kaide Çapı: 3 cm. Bezemeler: Diskus: Üç eşmerkezli daire kazıma bulunur, bir doldurma deliklidir. Omuz: Bezemesizdir. Kaide altında "kalp yaprak" kazıma (atölye işareti ?) bulunmaktadır. Burun: Yanma izleri belirgindir. Kulp: Delikli, yivli kulpludur. Üretim Yeri: İznik (Nikaia ?) Benzer Örnekleri: Bulunamadı. Tarihlendirme: 5. yüzyıl-7. yüzyıl sonu.

Kat. No: 6 (G. 9-a) Kazı Envanter No: 210. Buluntu Yeri: J 16 Plankaresi. Buluntu Seviyesi: +90.96-90.54 Hamur Rengi: 2.5 YR 5/6. Astar Rengi: 2. 5 YR 5/6. Az mika, az taşçık katkılı hamur orta serttir. Uzunluk: $8.5 \mathrm{~cm}$. Genişlik: $5.5 \mathrm{~cm}$. Yükseklik: 3.5 cm. Kaide Çapı: 2.3 cm. Bezemeler: Diskus: Üç eşmerkezli daire kazıma bulunur, bir doldurma deliklidir. Omuz: Bezemesizdir. Burun: Yanma izleri belirgindir. Kulp: Kırık ve noksandır. Üretim Yeri: İznik (Nikaia ?) Benzer Örnekleri: Bulunamadı. Tarihlendirme: 5. yüzyıl-7. yüzyıl sonu.

Kat. No: 7 (G. 9-b) Kazı Envanter No: 204. Buluntu Yeri: M 18+M 19 Plankareleri. Buluntu Seviyesi: +90.80-90.38 Hamur Rengi: 5 R 4/6. Astar Rengi: 5 R 5/6. Az mika, az taşçık katkılı hamur orta serttir. Uzunluk: $9.5 \mathrm{~cm}$. Genişlik: $5.9 \mathrm{~cm}$. Yükseklik: 3.6 cm. Kaide Çapı: 3 cm. Bezemeler: Diskus: Üç eşmerkezli daire kazıma bulunur, bir doldurma deliklidir. Omuz: Bezemesizdir. Burun: Yanma izi belirgindir. Kulp: Delikli, iki yivli kulpludur. Üretim Yeri: İznik (Nikaia ?) Benzer Örnekleri: Bulunamad1. Tarihlendirme: 5. yüzyıl-7. yüzyıl sonu.

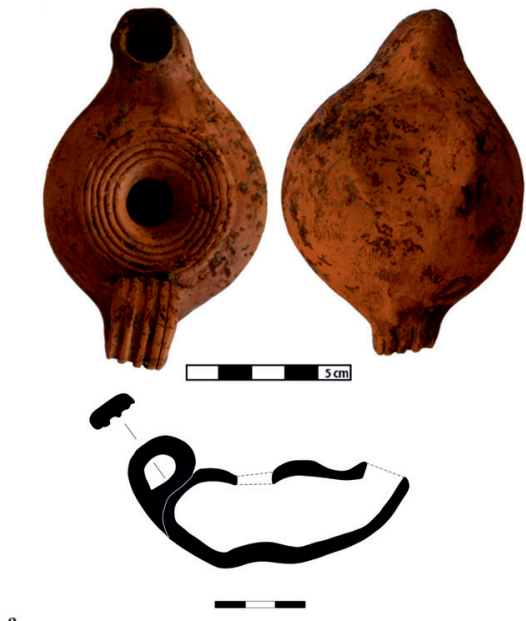

G. 10. Kat. No: 8 - 9 (F. İnanan, M. Akçınar, T. Akçınar, 2018)

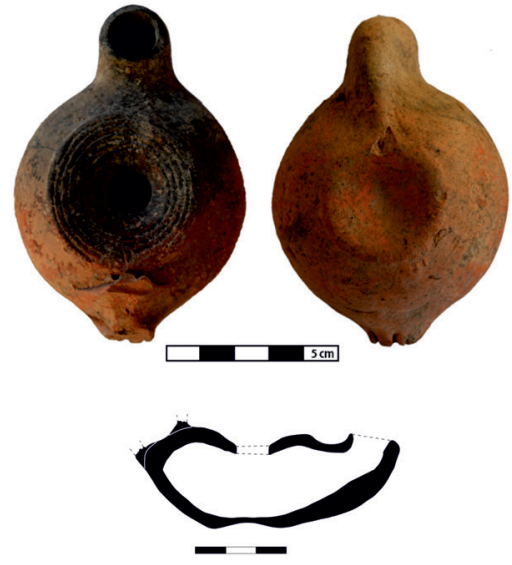

b. 
Kat. No: 8 (G. 10-a) Kazı Envanter No: 170. Buluntu Yeri: H 14 Plankaresi. Buluntu Seviyesi: +90.70-90.30 Hamur Rengi: 2.5 YR 5/4. Astar Rengi: 2. 5 YR 5/4. Az mika, az taşçık katkılı hamur orta serttir. Uzunluk: $9.5 \mathrm{~cm}$. Genişlik: $6.2 \mathrm{~cm}$. Yükseklik: 4.4 cm. Kaide Çapı: $2.8 \mathrm{~cm}$. Bezemeler: Diskus: Altı eşmerkezli daire kazıma bulunur, bir doldurma deliklidir. Omuz: Bezemesizdir. Burun: Yanma izleri belirgindir. Kulp: Delikli, yivli kulpludur. Üretim Yeri: İznik (Nikaia ?) Benzer Örnekleri: Ekin Meriç 2018: Plate 9-52, 53, 54, 55, 56, 57; Bruneau 1965: Plate XXVI-4723. Tarihlendirme: 5. yüzyıl-7. yüzyıl sonu.

Kat. No: 9 (G. 10-b) Kazı Envanter No: 169. Buluntu Yeri: H 14 Plankaresi. Buluntu Seviyesi: +91.07-90.70 Hamur Rengi: 5 R 4/6. Astar Rengi: 5 R 5/6. Az mika, az taşçık katkılı hamur orta serttir. Uzunluk: $8.7 \mathrm{~cm}$. Genişlik: $6.1 \mathrm{~cm}$. Yükseklik: 3.4 cm. Kaide Çapı: 2.2 cm. Bezemeler: Diskus: Beş eşmerkezli daire kazıma bulunur, bir doldurma deliklidir. Omuz: Sade bezemesizdir. Burun: Yanma izleri belirgindir. Kulp: Kırık ve noksandır. Üretim Yeri: İznik (Nikaia ?) Benzer Örnekleri: Ekin-Meriç 2018: Plate 9-52, 53, 54, 55, 56, 57; Bruneau 1965: Plate XXVI-4723. Tarihlendirme: 5. yüzy1l-7. yüzyıl sonu.

Kat. No: 10 (G. 11-a) Kazı Envanter No: 199. Buluntu Yeri: H 14 Plankaresi. Buluntu Seviyesi: +90.70-90.30 Hamur Rengi: 2.5 YR 4/6. Astar Rengi: 2. 5 YR 4/6. Az mika, az taşçık katkılı hamur orta serttir. Uzunluk: $8.7 \mathrm{~cm}$. Genişlik: $6.5 \mathrm{~cm}$. Yükseklik: $3 \mathrm{~cm}$. Kaide Çapı: $2.6 \mathrm{~cm}$. Bezemeler: Diskus: Dört eşmerkezli daire kazıma bulunur, bir doldurma deliklidir. Omuz: Bezemesizdir. Burun: Kırık ve noksan, yanma izleri belirgindir. Kulp: Kırık ve noksandır. Üretim Yeri: İznik (Nikaia ?) Benzer Örnekleri: Ekin Meriç 2018: Plate 9-52, 53, 54, 55, 56, 57; Bruneau 1965: Plate XXVI-4723. Tarihlendirme: 5. yüzy1l-7. yüzyıl sonu.

Kat. No: 11 (G. 11-b) Kazı Envanter No: 200. Buluntu Yeri: H 14 Plankaresi. Buluntu Seviyesi: +90.70-90.30 Hamur Rengi: 2.5 YR 5/4. Astar Rengi: 2. 5 R 5/4. Az mika, az taşçık katkılı hamur orta serttir. Uzunluk: $8.4 \mathrm{~cm}$. Genişlik: $6.1 \mathrm{~cm}$. Yükseklik: $3.7 \mathrm{~cm}$. Kaide Çapı: $2.3 \mathrm{~cm}$. Bezemeler: Diskus: Altı eşmerkezli daire kazıma bulunur, bir doldurma deliklidir. Omuz: Bezemesizdir. Burun: Kırık ve noksan, yanma izleri belirgindir. Kulp: Delikli, yivli kulpludur. Üretim Yeri: İznik (Nikaia ?) Benzer Örnekleri: Ekin-Meriç 2018: Plate 9-52, 53, 54, 55, 56, 57; Bruneau 1965: Plate XXVI-4723. Tarihlendirme: 5. yüzy11-7. yüzy1l sonu. 

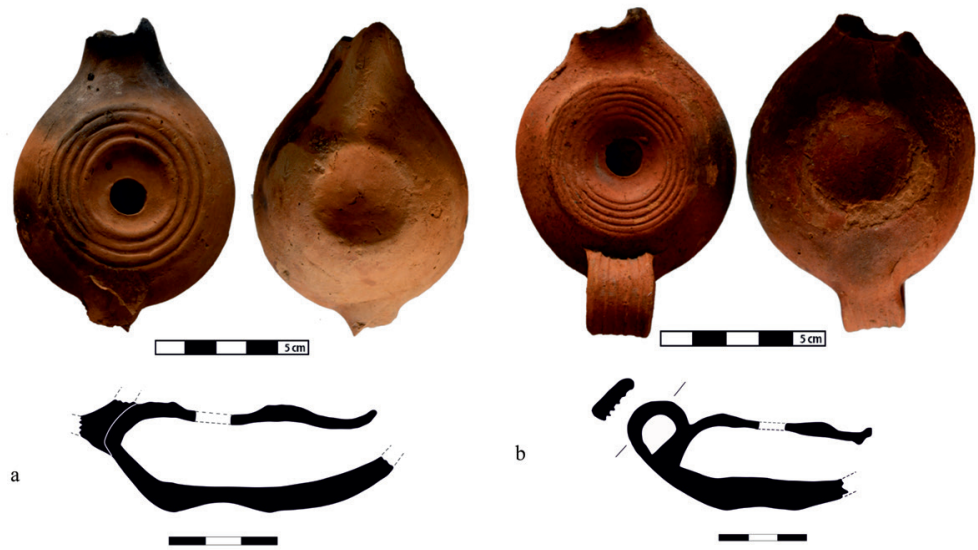

G. 11. Kat. No: 10 - 11 (F. İnanan, M. Akçınar, T. Akçınar, 2018)

Kat. No: 12 (G. 12-a) Kazı Envanter No: 216. Buluntu Yeri: J 13 Plankaresi. Buluntu Seviyesi: +90.97-90.71 Hamur Rengi: 10 R 4/6. Astar Rengi: 10 R 4/6. Az mika, az taşçık katkılı hamur orta serttir. Uzunluk: $7.3 \mathrm{~cm}$. Genişlik: $5.9 \mathrm{~cm}$. Yükseklik: 4 cm. Kaide Çapı: $2.1 \mathrm{~cm}$. Bezemeler: Diskus: Beş eşmerkezli daire kazıma bulunur, bir doldurma deliklidir. Omuz: Bezemesizdir. Burun: Kırık ve noksan, yanma izleri belirgindir. Kulp: Delikli, iki yivli kulpludur. Üretim Yeri: İznik (Nikaia ?) Benzer Örnekleri: Ekin Meriç 2018: Plate 9-52, 53, 54, 55, 56, 57; Bruneau 1965: Plate XXVI-4723. Tarihlendirme: 5. yüzy1l-7. yüzyıl sonu.
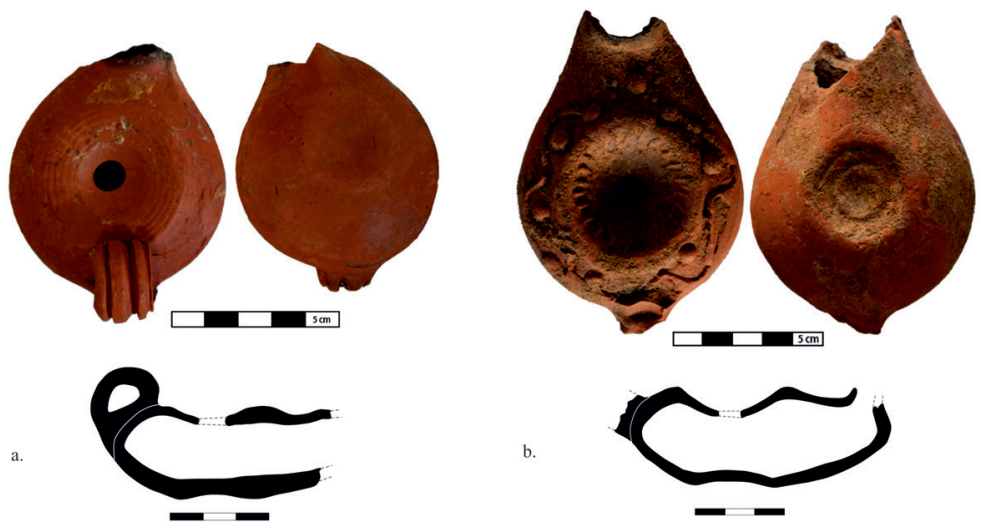

G. 12. Kat. No: 12 - 13 (F. İnanan, M. Akçınar, T. Akçınar, 2018)

\section{Grup Bitkisel ve Geometrik Desenli Bezemeli Kandiller (Kat. No: 13-23)}

"İznik Yerel Üretim” adı altında sınıflandırdığımız kandillerin ikinci grubu derin diskuslu, diskus merkezinde tek doldurma deliği bulunan, bir veya birden çok yivli ve delikli kulpludur (Kat. No: 13, 14, 15, 17, 20, 21). Bu tip içinde sınıflandırdığımız bazı kandillerin burun kanalı diğerlerinden (Kat. No: 16, 18, 19, 22 ) biraz daha geniş tutulmuş, genel görünümleri oval bir form kazanmıştır. Bir kandil (Kat. No: 23) ise 
gemi biçimli, daha geniş gövdesiyle küçük bir farklılık taşımakla birlikte mika ve kalsit katkılı hamur yapısı sebebiyle bu gruba dahil edilmiştir. 2. grupta bitkisel ve geometrik kompozisyonlara sahip kandiller bulunmaktadır. Bu grupta da, 1. grupta (Kat. No: 5) olduğu gibi tek bir kandil (Kat. No: 21) dibinde "yaprak" deseni kazımas1 bulunmaktadır. Bu grup kandillerin benzerleri İznik, Roma Tiyatrosu buluntuları arasında mevcuttur ${ }^{30}$. Ayrıca Delos buluntusu kandil, birebir benzer olmamakla birlikte, 1. grup örnekleri gibi, bu grup kandillerin form açısından yakın örneği olarak değerlendirilebilir ${ }^{31}$.

Kat. No: 13 (G. 12-b) Kazı Envanter No: 206. Buluntu Yeri: M 18+M 19 Plankareleri. Buluntu Seviyesi: +91.43-90.96 Hamur Rengi: 2.5 YR 5/4. Astar Rengi: 2. 5 YR 5/4. Az mika, az kalsit, az taşçık katkılı hamur orta serttir. Uzunluk: $9.3 \mathrm{~cm}$. Genişlik: $6.6 \mathrm{~cm}$. Yükseklik: $3.3 \mathrm{~cm}$. Kaide Çapı: $2.7 \mathrm{~cm}$. Bezemeler: Diskus: Merkezdeki doldurma deliğini sıralar haâlinde çevreleyen kısa, kabartma, düz çizgiler. Omuz: Tüm omuz kısmında kesintisiz devam eden dalgalı çizgi, çizginin " $U$ ” biçimli dalga kesimlerinin ortasında büyük birer nokta kabartma bulunur. Burun kanalı üzerinde omuz bandında yer alan noktalarla aynı büyüklükte tek nokta kabartma etrafına daha küçük boyutlu dokuz küçük nokta kabartma eklenmiş ve küçük bir madalyon oluşturulmuş. Burun: Kırık ve noksan, yanma izleri belirgindir. Kulp: Kırık ve noksandır. Üretim Yeri: İznik (Nikaia ?) Benzer Örnekleri: Ekin-Meriç 2018: Plate 9-53; Bruneau 1965: Plate XXVI-4729. Tarihlendirme: 5. yüzyıl-7. yüzyıl sonu.
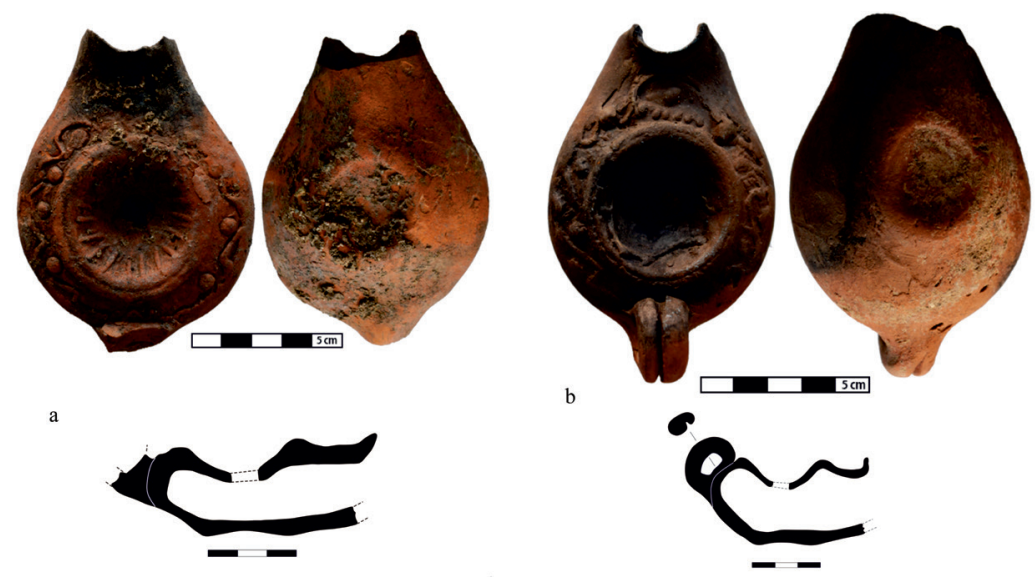

G. 13. Kat. No: 14 - 15 (F. İnanan, M. Akçınar, T. Akçınar, 2018)

Kat. No: 14 (G. 13-a) Kazı Envanter No: 215. Buluntu Yeri: M 17 Plankaresi. Buluntu Seviyesi: +91.10-90.85 Hamur Rengi: 5 R 4/4. Astar Rengi: 5 R 4/4 Az mika, az kalsit, az taşçık katkılı hamur orta serttir. Uzunluk: $8.8 \mathrm{~cm}$. Genişlik: $7 \mathrm{~cm}$.

30 Ekin-Meriç, "Late Roman Pottery From the Theatre of Nicaea in Bithynia," 75.

31 Bruneau, Les Lampes, Exploration Archéologique de Délos, XXVI, 143. 
Yükseklik: $3.4 \mathrm{~cm}$. Kaide Çapı: $2.8 \mathrm{~cm}$. Bezemeler: Diskus: Merkezdeki tek doldurma deliğinden omuza doğru uzanan 20 adet kısa, kalın kabartma düz çizgi. Omuz: Tüm omuz kısmında kesintisiz devam eden dalgalı çizgi, çizginin "U" biçimli dalga kesimlerinin ortasında büyük birer nokta kabartma, burun kanalı üzerinde ters "U" biçimli iki bitişik kabartma çizgi. Burun: Kırık ve noksan, yanma izleri belirgindir. Kulp: Kırık ve noksandır. Üretim Yeri: İznik (Nikaia ?) Benzer Örnekleri: Ekin Meriç 2018: Plate 9-53; Bruneau 1965: Plate XXVI-4729. Tarihlendirme: 5. yüzy1l-7. yüzy1l.

Kat. No: 15 (G. 13-b) Kazı Envanter No: 205. Buluntu Yeri: M 18+M 19 Plankareleri. Buluntu Seviyesi: +91.43-90.96 Hamur Rengi: 7.5 R 5/6-7.5 R 5/2. Astar Rengi: 7. 5 R 5/2. Az mika, az kalsit, az taşçık katkılı hamur orta serttir. Uzunluk: 8.1 cm. Genişlik: $6.1 \mathrm{~cm}$. Yükseklik: $4.1 \mathrm{~cm}$. Kaide Çapı: $2.3 \mathrm{~cm}$. Bezemeler: Diskus: Çok yıpranmış olan diskus kabartmasında, merkezdeki doldurma deliği etrafında dört adet geniş dalgalı kabartma çizgi ile bu dalgalı çizgilerin ortalarında iki ve/veya üç nokta kabartma izleri görülebilmektedir. Omuz: Tüm omuz kısmında kesintisiz devam eden dalgalı çizgi, çizginin "U" biçimli dalga kesimlerinin ortasında büyük birer nokta kabartma bulunur. Omzu dolanan ve kıvrım dallara benzeyen dalgalı çizginin bitimi, altı nokta kabartma ile burun kanalı üzerinde birleştirilmiş. Burun: Kırık ve noksan, yanma izleri belirgindir. Kulp: Delikli, tek yivli kulpludur. Üretim Yeri: İznik (Nikaia ?) Benzer Örnekleri: Ekin Meriç 2018: Plate 9-53; Bruneau 1965: Plate XXVI-4729. Tarihlendirme: 5. yüzyıl-7. yüzyıl sonu.
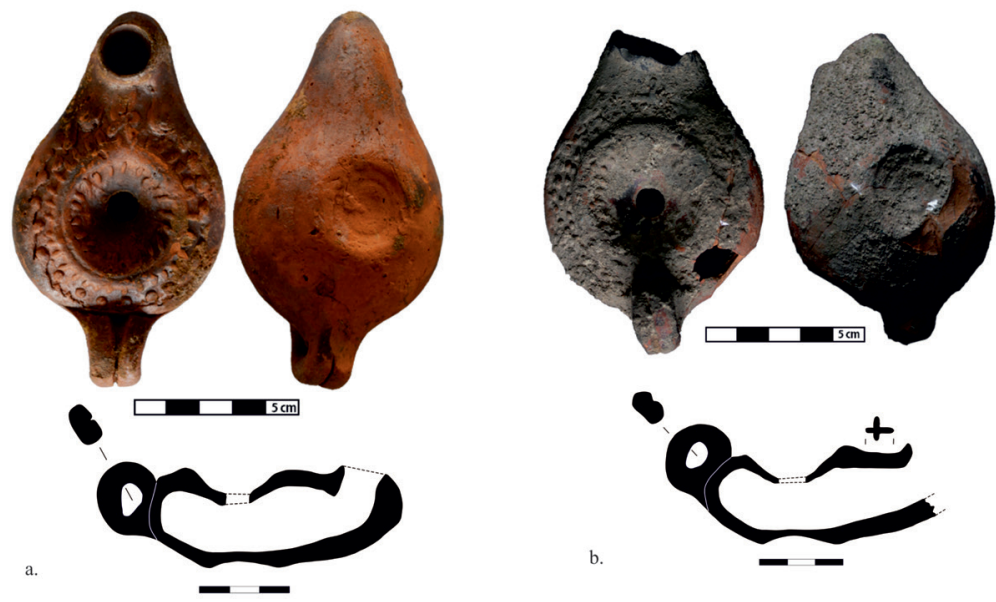

G. 14. Kat. No: 16 - 17 (F. İnanan, M. Akçınar, T. Akçınar, 2018)

Kat. No: 16 (G. 14-a) Kazı Envanter No: 217. Buluntu Yeri: L 17 Plankaresi. Buluntu Seviyesi: +90.97-90.68 Hamur Rengi: 2.5 YR 4/6. Astar Rengi: 2. 5 YR 4/6. Az mika, az kalsit, az taşçık katkılı hamur orta serttir. Uzunluk: $10.1 \mathrm{~cm}$. Genişlik: $5.8 \mathrm{~cm}$. Yükseklik: $3.5 \mathrm{~cm}$. Kaide Çapı: $1.9 \mathrm{~cm}$. Bezemeler: Diskus: Merkezdeki tek doldurma deliği etrafına dizilmiş yatay, kısa, kabartma çizgi ve noktalar. Omuz: İki 
şerit haâlinde düzenlenmiş omuz bandında, üst sırada kısa, hafif yatay kabartma çizgiler, çizgilerin altında yükseltilmiş kabartma nokta dizisi, en alt sırada tam bir düzen oluşturmayan, yatay, kısa, aşınmış kabartma çizgi şeridi bulunur. Burun: Yanma izi görülmemektedir. Kulp: Delikli, tek yivli kulpludur. Üretim Yeri: İznik (Nikaia ?) Benzer Örnekleri: Ekin Meriç 2018: Plate 9-53; Bruneau 1965: Plate XXVI-4729. Tarihlendirme: 5.yüzyıl-7.yüzyıl sonu.

Kat. No: 17 (G. 14-b) Kazı Envanter No: 214. Buluntu Yeri: L 18 Plankaresi. Buluntu Seviyesi: +91.57-91.15 Hamur Rengi: 2.5 YR 4/6. Astar Rengi: 2.5 R 4/6. Az mika, az kalsit, az taş̧̧ık katkılı hamur orta serttir. Uzunluk: $9.7 \mathrm{~cm}$. Genişlik: 6.7 $\mathrm{cm}$. Yükseklik: $4.3 \mathrm{~cm}$. Kaide Çapı: $2.7 \mathrm{~cm}$. Bezemeler: Diskus: Kandil yüzeyindeki korozyon sebebiyle dekorasyon tam saptanamamaktadır ancak kısa kabartma çizgi ve noktalarla oluşturulmuş geometrik bir düzenleme uygulanmıştır. Diskus merkezindeki bir doldurma deliğinin etrafını çevreleyen kısa, ince, yatay kabartma dizisi dışında motif görülmemektedir. Omuz: Omuzda bazı kısımlarda iki, bazı kısımlarda üçerli, özenli bir düzen oluşturmadan dizilmiş, yükseltilmiş küçük noktalar. Burun kanalı üzerinde iki kolu yıpranmış haç kabartma. Burun: Kırık ve noksan, yanma izi belirgin. Kulp: Delikli, tek yivli kulpludur. Üretim Yeri: İznik (Nikaia ?) Benzer Örnekleri: Ekin Meriç 2018: Plate 9-53; Bruneau 1965: Plate XXVI-4729. Tarihlendirme: 5. yüzyı1-7. yüzyıl sonu.

Kat. No: 18 (G. 15-a) Kazı Envanter No: 211. Buluntu Yeri: J 16 Plankaresi. Buluntu Seviyesi: +90.96-90.54 Hamur Rengi: 7.5 R 5/6. Astar Rengi: 7. 5 R 5/6. Az mika, az kalsit, az taşçık katkılı hamur orta serttir. Uzunluk: $8.3 \mathrm{~cm}$. Genişlik: 6 cm. Yükseklik: 4.9 cm. Kaide Çapı: 2.4 cm. Bezemeler: Diskus: Diskus diğer kandil buluntularımızdan farklı olarak çukur değildir. Merkezdeki tek doldurma deliği 20 kabartma motifle çevrelenmiş, bunlardan dokuzu nokta, diğerleri yatak, kısa kabartma çizgilerdir. Diskus omuzdan yüksek ve geniş bir bantla ayrılır. Bu kısımda iki sıra dalgalı kabartma çizgi bulunur ancak bazı çizgiler bölümlerde özensiz yatay çizgilere dönüşmüştür. Omuz: Tüm omuzda nispeten eşit aralıklarla yerleştirilmiş on altı yüksek kabartma nokta bulunur. Bunlara ek olarak sadece omzun, kulpa yakın kesimde, ilk sıra kadar düzenli olmayan ikinci bir nokta sırası daha vardır. Burun kanalı üzerinde bir dikey çizgiden iki yana uzayan ikişer yatay kabartma çizgi, çizgilerin hepsinin ucu birer büyük, yükseltilmiş nokta ile sonlandırılarak bitkisel bir görünüm yaratılmıştır. Burun: Kırık ve noksan, yanma izleri belirgindir. Kulp: Delikli, iki yivli kulpludur. Üretim Yeri: İznik (Nikaia ?) Benzer Örnekleri: Ekin Meriç 2018: Plate 9-53; Bruneau 1965: Plate XXVI-4729. Tarihlendirme: 5. yüzyıl-7. yüzyıl sonu.

Kat. No: 19 (G. 15-b) Kazı Envanter No: 209. Buluntu Yeri: J 16 Plankaresi. Buluntu Seviyesi: +90.96-90.54 Hamur Rengi: 10 R 4/6. Astar Rengi: 10 R 5/5. Az mika, az kalsit, az taşçık katk1lı hamur orta serttir. Uzunluk: $10.1 \mathrm{~cm}$. Genişlik: $5.9 \mathrm{~cm}$. 
Yükseklik: $4.1 \mathrm{~cm}$. Kaide Çapı: $2.7 \mathrm{~cm}$. Bezemeler: Diskus: Merkezdeki tek doldurma deliğinden omza doğru uzayan üçer dalı olan dokuz çizgisel yaprak motifi vardır. Omuz: Omzun iki yanında küçük zigzag çizgilerden oluşturulmuş dikey kabartma şerit bulunur. Burun kanalı üzerinde dört dikey kabartma çizgi iki sıra kabartma-zigzag çizgi mevcuttur. Burun: Yanma izi yok. Kulp: Delikli, iki yivli kulpludur. Üretim Yeri: İznik (Nikaia ?) Benzer Örnekleri: Ekin Meriç 2018: Plate 9-53; Bruneau 1965: Plate XXVI-4729. Tarihlendirme: 5. yüzy1l-7. yüzyıl sonu.
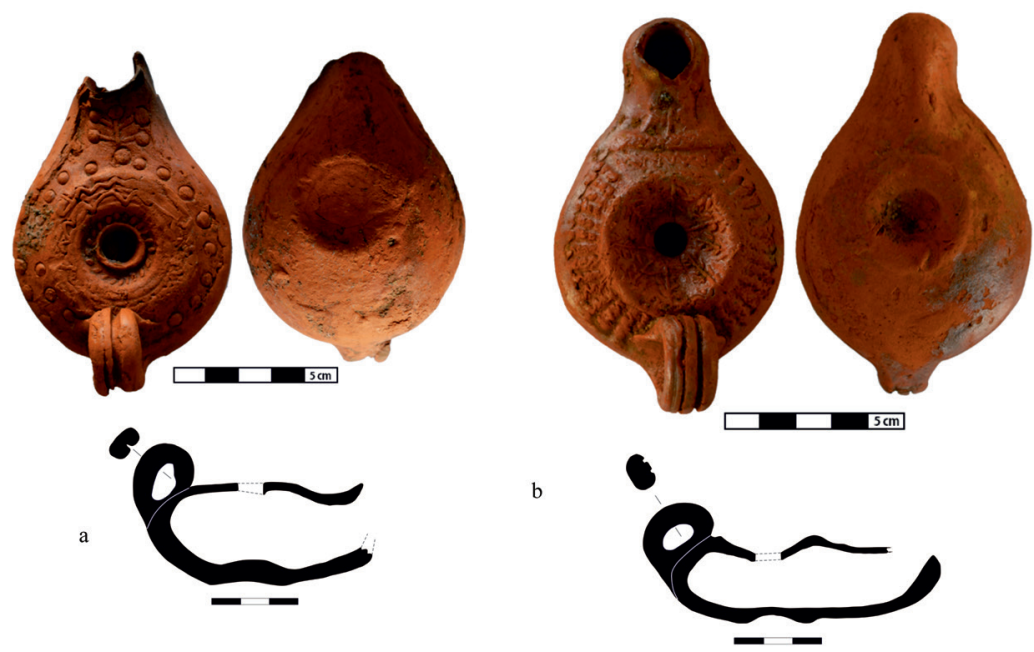

G. 15. Kat. No: 18 - 19 (F. İnanan, M. Akçınar, T. Akçınar 2018)

Kat. No: 20 (G. 16-a) Kazı Envanter No: 207. Buluntu Yeri: M 18+M 19 Plankareleri. Buluntu Seviyesi: +91.43-90.96 Hamur Rengi: 2.5 YR 4/4. Astar Rengi: 2. 5 YR 4/4. Az mika, az kalsit, az taşçı katkılı hamur orta serttir. Uzunluk: $8.3 \mathrm{~cm}$. Genişlik: $6.1 \mathrm{~cm}$. Yükseklik: $3.3 \mathrm{~cm}$. Kaide Çapı: $2.5 \mathrm{~cm}$. Bezemeler: Diskus: Diskus çevresi kısa kazıma çizgilerle omuzdan ayrılmış, diskus aynası bezemesiz, bir doldurma delikli. Omuz: İki ince kazıma çizgi arasına palmiye yapraklarını anımsatan bitkisel motiflerden oluşan bant düzenlenmiş, burun kanalı üzerinde diğer motiflerden daha büyük bir palmiye yaprağını anımsatan motif yerleştirilmiş. Burun: Kırık ve noksan, yanma izleri belirgindir. Kulp: Kırık ve noksandır. Üretim Yeri: İznik (Nikaia ?) Benzer Örnekleri: Ekin Meriç 2018: Plate 9-53; Bruneau 1965: Plate XXVI-4729. Tarihlendirme: 5. yüzyıl-7. yüzyıl sonu.

Kat. No: 21 (G. 16-b) Kaz1 Envanter No: 213. Buluntu Yeri: J 16 Plankaresi. Buluntu Seviyesi: +90.96-90.54 Hamur Rengi: 7.5 YR 6/4. Astar Rengi: 7. 5 R 6/4. Az mika, az kalsit, az taş̧̧ı katkılı hamur orta serttir. Uzunluk: $10.3 \mathrm{~cm}$. Genişlik: $7 \mathrm{~cm}$. Yükseklik: $4.6 \mathrm{~cm}$. Kaide Çapı: $3 \mathrm{~cm}$. Bezemeler: Diskus: Merkezdeki tek doldurma deliğinden omza uzayan yedi adet yaprak motifi bulunur. Omuz: Diskusta bulunan yaprak motiflerinin aynısı omzun iki yanında altışar tane, toplamda 12 adet olmak 
üzere simetrik biçimde yerleştirilmiştir. Burun kanalı üzerinde yıpranmış, ortası noktalı iki eşmerkezli daire ile yanında tek daire kazıma bulunur. Kaide altında "yaprak" kazıma (atölye işareti ?) yer almaktadır. Burun: Kırık ve noksan, yanma izleri belirgindir. Kulp: Delikli, tek yivli kulpludur. Üretim Yeri: İznik (Nikaia ?) Benzer Örnekleri: Form: Ekin-Meriç 2018: Plate 9-53; Ekin Meriç 2019: 349-Şekil.11; Bruneau 1965: Plate XXVI-4729. Tarihlendirme: 5. yüzyıl-7. yüzyıl sonu.
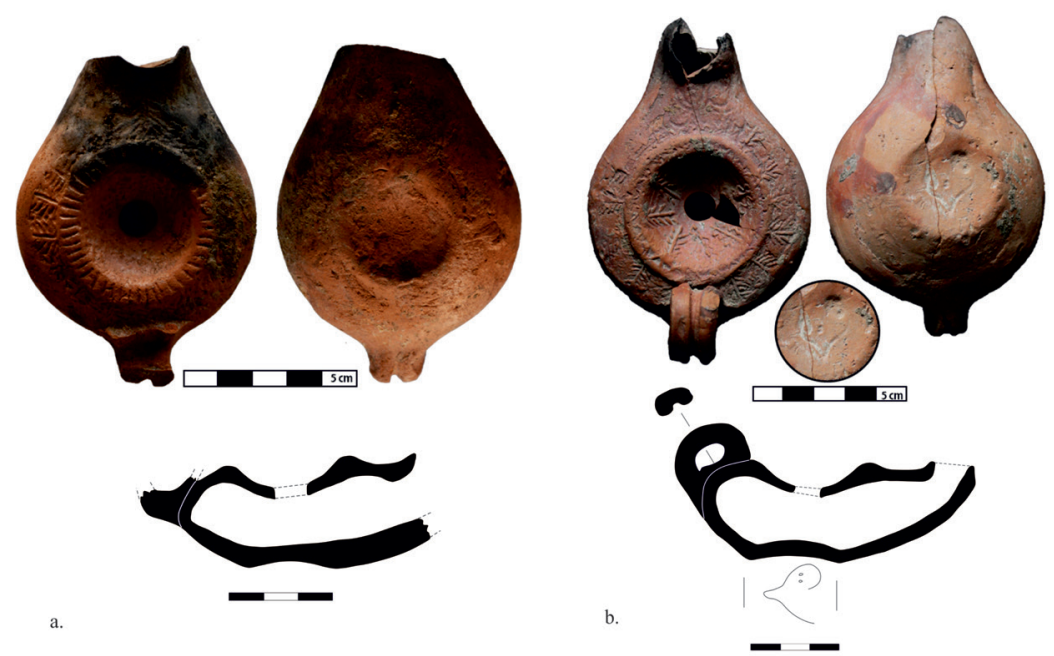

G. 16. Kat. No: 20 - 21 (F. İnanan, M. Akçınar, T. Akçınar, 2018)

Kat. No: 22 (G. 17-a) Kazı Envanter No: 201. Buluntu Yeri: H 14 Plankaresi. Buluntu Seviyesi: +90.70-90.30 Hamur Rengi: 7.5 R 5/6. Astar Rengi: 7. 5 R 5/6. Az mika, az kalsit, az taşçık katkılı hamur orta serttir. Uzunluk: $7.4 \mathrm{~cm}$. Genişlik: $5.4 \mathrm{~cm}$. Yükseklik: $3.5 \mathrm{~cm}$. Kaide Çapı: $2.1 \mathrm{~cm}$. Bezemeler: Diskus: Diskus, ikişerli noktalardan oluşan bir bantla sınırlandırılmış, geniş doldurma deliği yanında tanımlanamayan dört ayaklı bir hayvan figürü bulunur. Omuz: Bezemesizdir. Burun: Kırık ve noksan, yanma izi belirgindir. Kulp: Delikli, yivli kulpludur. Üretim Yeri: İznik (Nikaia ?) Benzer Örnekleri: Ekin Meriç 2018: Plate 9-53; Bruneau 1965: Plate XXVI-4729. Tarihlendirme: 5. yüzyıl-7. yüzyıl sonu.

Kat. No: 23 ( G. 17-b) Kaz1 Envanter No: 163. Buluntu Yeri: F 6+F-7+G 6+G 7 Plankareleri (Sondaj). Buluntu Seviyesi: +90.08- 89.65 Hamur Rengi: 2.5 YR 4/4. Astar Rengi: 2.5 R 4/4Az mika, az kalsit, az taşçık katkılı, hamur orta serttir. Uzunluk: $9.3 \mathrm{~cm}$. Genişlik: $6.5 \mathrm{~cm}$. Yükseklik: $3.2 \mathrm{~cm}$. Kaide Çapı: $3.7 \mathrm{~cm}$. Bezemeler: Diskus: Dört eş merkezli daire bulunur. Omuz: Omuzda düzensiz yerleştirilmiş kabartma noktalar, burun kanalı üzerinde yüksek kabartma nokta etrafında kazıma çizgiler vardır. Burun: Yanma izleri belirgindir. Kulp: Kırık ve noksandır. Üretim Yeri: İznik (Nikaia ?) Benzer Örnekleri: Bruneau 1965: Plate XXVI-4725, 4726. Tarihlendirme: 5. yüzyıl-7. yüzyıl sonu. 

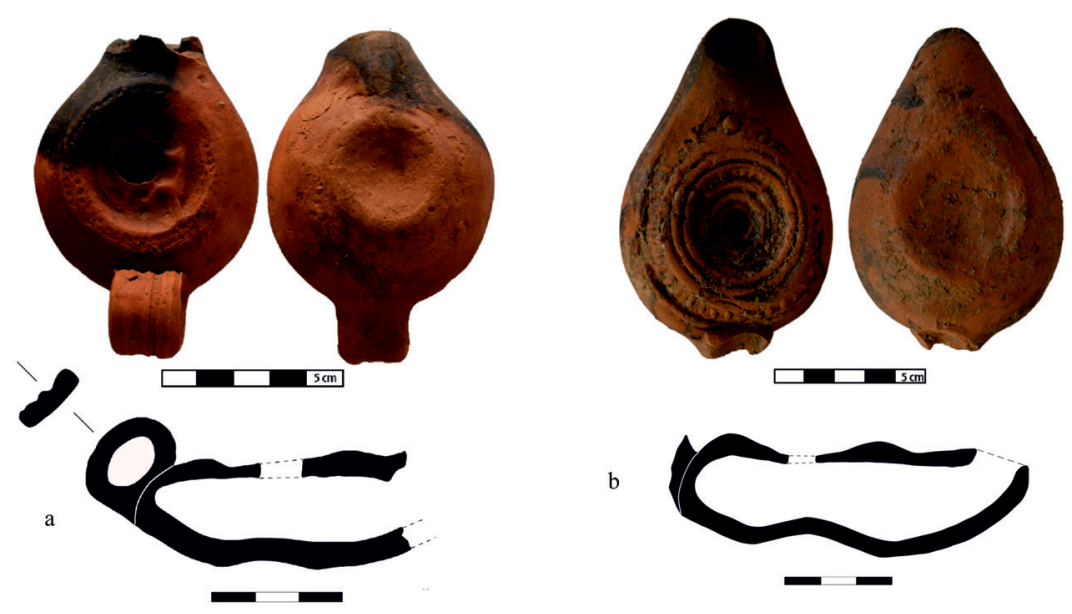

G. 17. Kat. No: 22 - 23 (F. İnanan, M. Akçınar, T. Akçınar, 2018)

\section{İstanbul Kapı Kandillerinde Atölye İşareti (?)}

İstanbul Kapı kazılarında ele geçen kandiller arasında, İznik atölyelerinde üretilmiş olmaları muhtemel görülen iki kandilin (Kat. No:5 ve Kat. No:22) dip kısmında "yaprak/sarmaşık yaprağı" kazıma bulunmaktadır. Kandil diplerinde atölye işareti kullanımı Antikçağ’ da yaygın bir uygulamadır. Dolayısıyla bu motifin bulunduğu yer gözetilerek, bir atölye işareti olması ihtimalini tartışmak gerekmektedir. İncelenen İznik Roma Tiyatrosu buluntularının yayınlarında, benzer kandillerde bu motifin varlığına ilişkin bilgiye rastlanmamıştır. Bu motifle tanınan bir atölye de tespit edilmemiştir. Fakat A. Karivieri'nin Geç Antik dönemde, Atina'daki kandil endüstrisini kaleme aldığı yayının kataloğunda bulunan birkaç kandil dikkat çekmektedir. Söz konusu katalogdaki bu kandillerin çoğunluğu 4. yüzyılın ilk yarısına tarihlendirilmiştir. Yuvarlak gövdeli, kısa burunlu bu kandiller, İznik kandillerinden farklı formdadır fakat kandillerin diplerinde sarmaşık yaprağ kazıma mevcuttur. İstanbul Kapı örneklerinden farklı olarak bu yapraklar saplarıyla birlikte çizilmiş$\operatorname{tir}^{32}$. Atina kataloğundaki kandillerden birinin dip kısmında, eş merkezli iki kazıma daire içinde bir sarmaşı yaprağı deseni ve etrafında tersten yazılmış "BPOMIOY" (Bromios'un) ifadesi yer almaktadır ${ }^{33}$. Karivieri, "imza" olarak tanımladığı bu motifin sadece belirli kandil tiplerinde bulunduğunun altını çizmiştir. Yaprak motifinin bazen beraberinde bir yazıtla bazen de yaprağın altına veya üstüne kazınan bir veya birkaç harfle birlikte kullanıldığını belirtmiştir. Karivieri, Atina kandillerindeki bu harfleri imalatçı işareti olarak tanımlamıştır. Bununla birlikte harflerin, kandil üretimi organizasyonuyla ilişkili bir sembol olarak kullanılabileceği, bir arketip kan-

32 Karivieri, The Athenian Lamp Industry in the Late Antiquity, Fig. 27-28, P1.1 / 1, 9, P1.2 / 29, P1.29 / 300 , 301, 302, 303, P1.30 / 32, P1.34 / 11.

33 Karivieri, The Athenian Lamp Industry in the Late Antiquity, Fig.23-3339. 
dilden üretilen farklı bir kandil tipinin veya aynı kalıptan türetilen farklı bir çeşidin işareti olabileceği gibi farklı öneriler de sunmuştur. Araştırmacı Atina atölyelerinde motiflerinin yanına harf ekleme uygulamasının 4. yüzyılda kandillerin sırlanmaya başlamasına kadar devam ettiğini, kazıma dalların ise varlığını 6. yüzyıla kadar koruduğunu ifade etmiştir ${ }^{34}$.

İznik Yerel Üretim başlığı altında tasniflediğimiz kandillerdeki imza/işaret (?) sapsız, kalp biçimli bir sarmaşık yaprağıdır. Atina örneklerinden form ve tarihlendirme dışında, sapsız çizilmiş olmasıyla da ayrılmaktadır. Fakat hem yaprak desenlerinin genel formu hem de tek bir kandilde tespit edilen "Bromios'un" ifadesi göz ardı edilmemelidir. Bu kelime, şarap ve bağ tanrısı Dionysos'un epithetonlarından biridir ${ }^{35}$. Bu noktada İznik kentinin Dionysos kültü ile ilişkisini hatırlamakta fayda vardır ${ }^{36}$. Antik Nikaia kentinin kuruluş öykülerinden biri mitolojik bir aşk öyküsüne dayandırılmaktadır ve bu öykü Dionysos ile bağlantılıdır. Nymphe Nikaia, Irmak Tanrısı Sangarios'un (Sakarya) kızı, günlerini Askania (İznik Gölü) çevresindeki orman ve kırlarda dolaşarak, avlanarak geçirmektedir. Dionysos, Nikaia’yı görür görmez âşık olur. Ancak hiçbir erkekle birlikte olmamaya kararlı olan Nymphe onu reddeder. Reddedilmeyi kabullenemeyen Dionysos, Nikaia’nın su içtiği kaynağın suyunu şaraba çevirir. Su sanarak şarap içen Nikaia sarhoş olunca Dionysos ile birlikte olur. Öyküye göre, Dionysos bu perinin onuruna bir kent kurar ve kentin adını "Nikaia" koyar"

Nikaia kentinin soyunu Dionysos’a bağladığı bilgisi bir yazıt ile belgelenmiştir. Kentin doğusundaki Lefke Kapısı üzerinde, arşitravda M.S. 123 yılında Hadrianus'a adanan sunu yazıtında, kent soyunun Dionysos ve Herakles'e bağlandığı aktarılmıştır $^{38}$. Aynı yazıtın kentin kuzeyindeki en büyük ve en önemli kapısı olan İstanbul Kapı' da da yer almış olabileceği, sonraki yüzyıllarda yapılan onarımlar sırasında bazı değişiklikler meydana geldiği düşünülmektedir ${ }^{39}$. Yazıtlar dışında kentte darbedilmiş sikkelerin betimlerinde de kentin bu kült ile bağlantısı, şarap ve bağ Tanrısı şerefine oyunlar düzenlendiği görülmektedir ${ }^{40}$. İznik kentinin Dionysos ile ilişkisi, nicelik açısından az, nitelik açısından önemli ve yadsınamayacak verilerle belgelenmiştir.

34 Karivieri, The Athenian Lamp Industry in the Late Antiquity, 26-27.

35 Dionysos'un çok sayıdaki epithetonlarından biri olan "Bromios” şiddetli ve gürültülü anlamları taşıyan bir sıfattır. Bülent Öztürk, Yazıtlar Işı̆̆ında Roma Imparatorluk Çă̆ı Küçükasyası ’nda Dionysos Kültü (İstanbul: Arkeoloji ve Sanat Yayınları, 2010), 198.

36 Hülya Boyana, "Nikaia Kenti ve Dionysos Kültü”. Uluslararası Kara Mürsel Alp ve Kocaeli Tarihi Sempozуити II, Ed. Haluk Selvi, Bilal Çelik, Ali Yeşildal (Kocaeli: Pelikan Basım, 2016), 43-59.

37 Şefik Can, Klasik Yunan Mitolojisi (İstanbul, y.y, 1970), 481; Azra Erhat, Mitoloji Sözlüğü (İstanbul: Remzi Kitabevi, 2011), 217; Hélène Frangoulis, "Passion et Narration: Nonnos et le Roman,” Passions, Vertus et vices Dans l'ancien Roman, Ed. Bernard Pouderon, Cecile Bostpouderon (Lyon: Maison de 1' Orient et de la Méditerranée, 2009), 367-376.

38 Bülent Öztürk, Yazıtlar Işı̆̆̆ında Roma Imparatorluk Çağı Küçükasyası’nda Dionysos Kültü, 77.

39 Sencer Şahin, Bithynische Studien / Bithynia İncelemeleri (Bonn: Rudolf Habelt Verlag Gmbh, 1978), 87-88.

40 Hülya Boyana, "Nikaia Kenti ve Dionysos Kültü," 49. 
$\mathrm{Bu}$ verilerin dışında, M.S. 10. veya 11. yüzyılda bir din bilginin elindeki Notitiae episcopatuum nüshasına, el yazısıyla aldığı "Metropolis Nikaia" notu dikkat çekmektedir. Bu notun Arrianos'un Bithyniaka kitabından alıntılandığı ve notta Nikaia kentinin en eski adının sarmaşığı, asması bol olan anlamındaki "Helikore" kelimesi olduğu ifade edilmektedir ${ }^{41}$. Bitkilerin doğasına hakim olan Dionysos'un en sevdiği atribülerinden biri sarmaşık yapraklarından örülen tacıdır ${ }^{42}$ ve Helenistik Dönem'den beri Dionysos kültünün bir parçasıdır ${ }^{43}$. Birbirinden ayrı görünen bu bilgilere, Dionysos kültü ve Nikaia kenti çerçevesinden bakıldığında; Dionysos kültünün önemli simgelerinden biri olan, aynı zamanda Nikaia kentinde sıklıkla rastlanan sarmaşık dallarının veya yapraklarının, kentteki zanaatkarların üretimlerinde işaret/imza/simge olarak seçilmesi kuvvetle muhtemeldir.

\section{Sonuç}

Çalışmamız kapsamında Antik Nikaia kentinin en görkemli kapısı olan ve kentin kuzeyinde yer alan İstanbul Kapı ve yakın çevresinde yapılan restorasyon amaçlı kazı çalışmalarında, konteksiz ele geçen 23 tüm ve tüme yakın pişmiş toprak kandil belgelenmiştir. Bu kandillerden biri (Kat. No: 1) Pontika üretimi olarak tanımlanmış, benzerleri doğrultusunda 4. ve 5. yüzyıllara tarihlendirilmiştir. İki kandil (Kat. No: 2, Kat. No: 3 ) 5.-6. yüzyılların en popüler gruplarından biri olan Kuzey Afrika üretimidir. Form ve genel özellikleri itibarıyla, Küçük Asya üretimi olarak tanımlanan (Kat. No: 4) bir kandil ise yine benzer örnekleri doğrultusunda 4.-5. yüzyıllara tarihlendirilmiștir. Çalıșmamızın önemli bölümünü oluşturan 19 kandilin (Kat. No: 5-23) form ve dekorasyonlarının genel görünümleri göz önüne alındığında, Küçük Asya üretimleri içinde değerlendirilmesi uygundur. Fakat çalışmamız kapsamında, bu kandillerin form ve bezeme özelliklerinin birebir paylaşan kandillere başka yerleşimlerde rastlanmamıştır. Sadece Delos kentindeki bir kandil form açısından bu kandillerle benzerlik gösterir ancak Delos buluntusunda burun daha kısadır. Bu 19 kandilin en yakın örnekleri kentin bir başka önemli merkezi olan anıtsal yapıda, Antik Roma Tiyatrosu Kazıları'nda ele geçmiştir.

İznik, Antik Roma Tiyatrosu Kazıları'nda, bu tipe yakın kandiller referans al1narak, İstanbul Kapı kandilleri içindeki form ve bezeme açısından yakın örnekler "Yerel Üretim" başlığında sınıflandırılmıștır. Roma Tiyatrosu buluntuları arasında Yerel Üretim 1. grup kandillerinin form-bezeme açısından çok yakın örnekleri bulunmuştur. Yerel Üretim 2. grup kandillerin form açısından aynı, bezeme açısından farklı özellikler gösteren örneklerinin dışında, bir kandilin (Kat. No: 21) hem form

41 Sencer Şahin, "Hellenistik ve Roma Çağlarında İznik/Nikaia", Tarih Boyunca İznik (İstanbul: İş Bankası Kültür Yayınları, 2004), 6; Sencer Şahin, "Yazıtların Diliyle İznik’te (Nikaia) Tarih", V. Araşstırma Sonuçlar Toplantısı, c. 1 (İstanbul: Kültür Varlıkları ve Müzeler Genel Müdürlüğü, 1987), 373.

42 Thomas H. Carpenter, Antik Yunan'da Sanat ve Mitoloji (İstanbul: Homer Kitabevi, 2007), 37.

43 Walter Friedrich Otto, Dionysos: Myth and Cult (Bloomington : Indiana University Press, 1965), 153. 
ve hem bezeme açısından çok benzer bir örneği de ele geçmiştir ${ }^{44}$. A. Ekin Meriç tarafından bu kandiller "Yerel Üretim" olarak tanıtılmış ve 5.-7. yüzyıllar arasında tarihlendirilmiştir ${ }^{45}$. Araştırmacı, Nikaia kentinin Justinianos Dönemi’nde önemli bir seramik üretim merkezi olduğunu belirtmiştir. Kazılar sonucunda tiyatronun kullanım evrelerinin belirlendiğini, 9. yüzyıldan sonra tiyatro ve çevresinin seramik üretilen işlik ve atölye alanı olarak kullanılmaya devam ettiğini bildirmiştir ${ }^{46}$.

İstanbul Kapı Kazıları tamamlanmıştır ve bu çevrede yakın zamanda başka bir proje planlanmamaktadır. Ancak Roma Tiyatrosu Kazıları devam etmektedir. Kazılar devam ettikçe kandil buluntularının artması, kandillerin form ve bezeme repertuarının genişleyeceği tahmin edilmektedir. Bunun yanında atölye işareti olabileceğini düşündüğümüz sarmaşık yaprağı motifinin örneklerinin çoğalması da olasıdır. Antik Roma Tiyatrosu ve İstanbul Kapı Kazısı kandilleri içinde "Yerel Üretim" başlığında sınıflandırılan bu kandillerin atölyeleri, hamur, form ve bezeme özellikleri, Anadolu' da ve Anadolu dışındaki dağılım alanları üzerine yanıtlanacak pek çok soru bulunmaktadır. Yüzyıllardır seramik üretimin sürdüğü İznik’te artacak buluntular ve yapılacak arkeometrik analizlerin sonuçları 1şı̆̆ında, çalışmamız kapsamında incelenip tanıtılan kandillerin, tekrar değerlendirilmesi gerekeceği öngörülmektedir.

Hakem Değerlendirmesi: Dış bağımsız.

Çıkar Çatışması: Yazarlar çıkar çatışması bildirmemiştir.

Finansal Destek: Yazarlar bu çalışma için finansal destek almadığını beyan etmiştir.

Peer-review: Externally peer-reviewed.

Conflict of Interest: The authors have no conflict of interest to declare.

Grant Support: The authors declared that this study has received no financial support.

\section{Kaynakça/References}

Bailey, Donald Michael. A Catalogue of the Lamps in the British Museum, III. Roman Provincial Lamps, London: British Museum Publications, 1988.

Boardman, John, Michael Ballance, Spencer Corbett ve Sinclair Hodd. Excavations In Chios 19521955, Byzantine Emporio. Athens: British School at Athens, 1989.

Bovon, Anne. Lampes d'Argos (Études péloponnésiennes V). Paris, Librairie Philosophique J. Vrin, 1966. Boyana, Hülya. "Nikaia Kenti ve Dionysos Kültü". Uluslararası Kara Mürsel Alp ve Kocaeli Tarihi Sempozyuтu II, Ed. Haluk Selvi, Bilal Çelik, Ali Yeşildal (Kocaeli: Pelikan Basım, 2016), 43-59.

Broneer, Oscar. Corinth: Terracotta Lamps, Vol. IV, Part II (Massachusetts: American School of Classical Studies at Athens, 1930).

Broneer, Oscar. Isthmia: Terracotta Lamps. Vol. III. Princeton: American School of Classical Studies at Athens, 1977.

44 Ekin Meriç, "İznik Tarihini Simgeleyen Bir Anıt: Antik Roma Tiyatrosu,” 349, Şekil 11.

45 Ekin Meriç, "Late Roman Pottery From the Theatre of Nicaea in Bithynia," 69-87.

46 Ekin Meriç, "İznik Tarihini Simgeleyen Bir Anıt: Antik Roma Tiyatrosu,” 349. 
Bruneau, Philippe. Les Lampes, Exploration Archéologique de Délos, XXVI. Paris, Éditions de Boccard, 1965.

Bussière, Jean ve Birgitta Lindros Wohl. Ancient Lamps in the J. Paul Getty Museum. Los Angeles: J. Paul Getty Museum, 2017.

Can, Şefik. Klasik Yunan Mitolojisi. İstanbul, y.y., 1970.

Carpenter, Thomas H. Antik Yunan'da Sanat ve Mitoloji, İstanbul: Homer Kitabevi, 2007.

Chrzanovski, Laurent ve Denis Zhuravlev. Lamps From Chersonesos in the State Historical Museum Moscow. Rome: L'ERMA di Bretschneider,1998.

Dağl1, Günsel. "Hadrianoupolis Surları Kurtarma Kazısında Bulunan Roma ve Bizans Dönemi Kandilleri”. Yüksek Lisans Tezi, Dokuz Eylül Üniversitesi, 2008.

Ekin Meriç, Aygün. "Late Roman Pottery From the Theatre of Nicaea in Bithynia". Anatolia Antiqua XXVI (2018): 69-87.

Ekin Meriç, Aygün. "İznik Tarihini Simgeleyen Bir Anıt: Antik Roma Tiyatrosu”. Dokuz Eylül Üniversitesi Sosyal Bilimler Enstitüsü Dergisi 21/2 (2019): 339-355.

Erhat, Azra. Mitoloji Sözlüğ̈̈. İstanbul: Remzi Kitabevi, 2011.

Firat, Murat. “A Vaulted Tomb in Isparta/Çünür and Its Finds”. Arkeoloji Dergisi XXI. (2016): 127-140.

Frangoulis, Hélène. "Passion et Narration: Nonnos et le Roman". Passions, Vertus et Vices Dans l'ancien Roman, Ed. Bernard Pouderon, Cecile Bostpouderon (Lyon: Maison de l' Orient et de la Méditerranée, 2009): 367-376.

İnanan, Filiz. “İzmir Arkeoloji Müzesi’nden Bir Grup Pişmiş Toprak Kandil”. Sanat Tarihi Dergisi XVI/1 (2007): 49-65.

Karakaya, Hasan. "Edirne (Hadrianopolis) Kalesi 2008 Y11 Kurtarma Kazıları”. Müze Kurtarma Kazllarl Semineri 18 (2010): 105-134.

Karivieri, Arja. The Athenian Lamp Industry in the Late Antiquity. Helsinki: Foundation of the Finnish Institute at Athens, 1996.

Katsioti, Angeliki. The Lamps of Late Antiquity From Rhodes, 3rd-7th centuries AD. Oxford: Archaeopress Archaeology, 2017.

Lightfoot, Chistopher S. Amorium Report 2. Research Papers and Technical Reports. Oxford: Bar International Series 1170, 2003.

Miltner, Franz. Das Cömeterium der Sieben Schlöfer, Forschungen in Ephesos IV/2. Wien, 1937.

Otto, Walter Friedrich. Dionysos: Myth and Cult. Bloomington: Indiana University Press, 1965.

Öztürk, Bülent. Yazıtlar Işı̆̆ında Roma İmparatorluk Çağı Küçükasyası'nda Dionysos Kültü. İstanbul: Arkeoloji ve Sanat Yayınları, 2010.

Perlzweig, Judith. Lamps of the Roman Period, First to Seventh Century after Christ Agora VII. Princeton: American School of Classical Studies at Athens, 1961.

Şahin, Sencer. "Yazıtların Diliyle İznik’te (Nikaia) Tarih,” V. Araştırma Sonuçları Toplantısı, 1. Cilt. İstanbul: Kültür Varlıkları ve Müzeler Genel Müdürlüğ̈̈, 1987, 369-374.

Şahin, Sencer. "Hellenistik ve Roma Çağlarında İznik/Nikaia", Tarih Boyunca İznik. Ed. Oktay Aslanapa, Halil İnalcık. İstanbul: İş Bankası Kültür Yayınları, 2004, 3-23.

Şahin, Sencer. Bithynische Studien/Bithynia İncelemeleri (Bonn: Rudolf Habelt Verlag Gmbh, 1978).

Topoleanu, Florin. Lămpile Antice din Collectiile Muzeului Judetean de Istorie şi Arheologie Prahova - Ploieşti. Ploieşti: Oscar Print, 2012. 